\title{
Lipopolysaccharide immune stimulation but not $\beta$-mannanase supplementation affects maintenance energy requirements in young weaned pigs
}

\author{
Nichole F. Huntley ${ }^{1}$, C. Martin Nyachoti ${ }^{2}$ and John F. Patience ${ }^{1 *}$
}

\begin{abstract}
Background: Pathogen or diet-induced immune activation can partition energy and nutrients away from growth, but clear relationships between immune responses and the direction and magnitude of energy partitioning responses have yet to be elucidated. The objectives were to determine how $\beta$-mannanase supplementation and lipopolysaccharide (LPS) immune stimulation affect maintenance energy requirements (MEm) and to characterize immune parameters, digestibility, growth performance, and energy balance.

Methods: In a randomized complete block design, 30 young weaned pigs were assigned to either the control treatment (CON; basal corn, soybean meal and soybean hulls diet), the enzyme treatment (ENZ; basal diet $+0.056 \% \beta$-mannanase), or the immune system stimulation treatment (ISS; basal diet $+0.056 \% \beta$-mannanase, challenged with repeated increasing doses of Escherichia coli LPS). The experiment consisted of a 10-d adaptation period, 5-d digestibility and nitrogen balance measurement, $22 \mathrm{~h}$ of heat production (HP) measurements, and $12 \mathrm{~h}$ of fasting HP measurements in indirect calorimetry chambers. The immune challenge consisted of 4 injections of either LPS (ISS) or sterile saline (CON and ENZ), one every $48 \mathrm{~h}$ beginning on d 10. Blood was collected pre- and post-challenge for complete blood counts with differential, haptoglobin and mannan binding lectin, 12 cytokines, and glucose and insulin concentrations.

Results: Beta-mannanase supplementation did not affect immune status, nutrient digestibility, growth performance, energy balance, or $\mathrm{ME}_{\mathrm{m}}$. The ISS treatment induced fever, elevated proinflammatory cytokines and decreased leukocyte concentrations $(P<0.05)$. The ISS treatment did not impact nitrogen balance or nutrient digestibility $(P>0.10)$, but increased total $\mathrm{HP}(21 \%)$ and $\mathrm{ME}_{\mathrm{m}}(23 \%)$, resulting in decreased lipid deposition (-30\%) and average daily gain $(-18 \%)(P<0.05)$

Conclusions: This experiment provides novel data on $\beta$-mannanase supplementation effects on immune parameters and energy balance in pigs and is the first to directly relate decreased $A D G$ to increased $M E_{m}$ independent of changes in feed intake in immune challenged pigs. Immune stimulation increased energy partitioning to the immune system by $23 \%$ which limited lipid deposition and weight gain. Understanding energy and nutrient partitioning in immune-stressed pigs may provide insight into more effective feeding and management strategies.
\end{abstract}

Keywords: Acute phase proteins, $\beta$-Mannan, Cytokines, Digestibility, Feed induced immune response, Heat production, Inflammation, Lipopolysaccharide, Nitrogen balance, Swine

\footnotetext{
* Correspondence: jfp@iastate.edu

'Department of Animal Science, lowa State University, Ames, IA 50011, USA

Full list of author information is available at the end of the article
}

(c) The Author(s). 2018 Open Access This article is distributed under the terms of the Creative Commons Attribution 4.0 International License (http://creativecommons.org/licenses/by/4.0/), which permits unrestricted use, distribution, and reproduction in any medium, provided you give appropriate credit to the original author(s) and the source, provide a link to the Creative Commons license, and indicate if changes were made. The Creative Commons Public Domain Dedication waiver (http://creativecommons.org/publicdomain/zero/1.0/) applies to the data made available in this article, unless otherwise stated. 


\section{Background}

The negative influence of an immune challenge on animal growth is well established. Pro-inflammatory cytokines orchestrate an immune response resulting in fever, acute phase protein (APP) production, and leukocyte proliferation, each of which requires additional energy and amino acids (AA). Therefore, a perceived immune challenge can theoretically partition energy and nutrients away from productive processes such as muscle growth and negatively impact the efficiency and cost of meat production [1]. Innate immune activation occurs when pathogen-associated molecular patterns are detected such as the lipid-A component of lipopolysaccharide (LPS) from gram-negative bacteria [2]. However, certain dietary components, such as $\beta$-mannan in soybean, copra, and palm kernel meals, mimic carbohydrate structures on pathogen surfaces [3] and have previously been shown to activate the innate immune system $[4,5]$, termed a feed-induced immune response (FIIR).

To inhibit a $\beta$-mannan derived FIIR, interest in $\beta$-mannanase enzyme supplementation has increased. It is hypothesized that the hydrolyzed manno-oligosaccharides can no longer crosslink and stimulate multiple mannose receptors, thus reducing immune stimulation and associated energy costs. Research in poultry demonstrated that $\beta$-mannanase decreased plasma APP concentration and improved growth performance and feed efficiency leading to the conclusion that $\beta$-mannanase supplementation spared energy through prevention of the FIIR [6, 7]. In pigs, performance responses to $\beta$-mannanase are less consistent than in poultry and reports on immune responses are limited and effects on energy partitioning have yet to be evaluated.

Nutrient partitioning in pigs during a pathogen challenge has received more attention, often utilizing a LPS challenge model [8]. Physiological responses to a LPS challenge in pigs have been well characterized. Similar to disease challenges, LPS induces anorexia, fever, and nutrient repartitioning leading to decreased growth and efficiency $[1,2,9]$. Fever is an energetically expensive process and its effects on sheep and human maintenance energy requirements have been estimated [10]. Immune system activation also significantly shifts glucose metabolism and glucose requirements during an LPS challenge in pigs have been estimated to be approximately $1.1 \mathrm{~g} /\left(\mathrm{kg} \mathrm{BW}^{0.75} \cdot \mathrm{h}\right)$ [11]. Yet few studies have addressed comprehensive changes in energy partitioning during an immune response and clear relationships between measured immune responses and the direction and magnitude of changes in energy partitioning have yet to be elucidated.

Therefore, the objectives of this experiment were to determine how $\beta$-mannanase supplementation and innate immune stimulation each affect maintenance energy requirements and to characterize changes in immune parameters, nutrient digestibility, growth performance, and energy balance. We hypothesized that innate immune stimulation would increase maintenance energy requirements by initiating a cytokine-driven febrile response and inflammatory state, and that $\beta$-mannanase supplementation would decrease maintenance energy requirements through an energy sparing effect of FIIR prevention.

\section{Methods}

All experimental procedures adhered to guidelines for the ethical and humane use of animals for research and were reviewed and approved by the University of Manitoba Animal Care Committee.

\section{Animals and experimental design}

Thirty growing barrows [(Yorkshire $\times$ Landrace $) \times$ Duroc] were acquired from the Glenlea Swine Research Unit, University of Manitoba at an average body weight $(\mathrm{BW})$ of $9.60 \pm 2.00 \mathrm{~kg}$. The experiment was conducted using a randomized complete block design. Pigs were blocked by weight and randomly assigned to one of three treatments (Table 1). A staggered time course was utilized to accommodate the limited number of calorimetry chambers available, whereby 10 blocks of three pigs each (one pig per treatment) began the experiment $4 \mathrm{~d}$ after the previous block. Day one BW was similar among treatments $(10.27 \pm 0.08 \mathrm{~kg})$.

\section{Experimental diets, treatments and procedures}

All diets were formulated on the ratio of standardized ileal digestible lysine to metabolizable energy (ME) and met or exceeded all specified nutrient requirements of growing pigs from 11 to $25 \mathrm{~kg}$ [12]. Pigs were fed at 2.5 times their maintenance ME requirements [12], once daily at 08:00 $\mathrm{h}$ and had free access to water at all times. Pigs were fed a common pre-trial diet (Additional file 1: Table S1) that was corn-soybean meal-based. The experimental basal diet (Table 2) was formulated with high soybean meal and soybean hull inclusion levels to increase dietary $\beta$-mannan concentration.

Due to the availability of three indirect calorimetry chambers, three experimental treatments were evaluated (Table 1). The control treatment $(\mathrm{CON})$ received the basal diet, while the enzyme treatment (ENZ) received CON supplemented with $0.056 \% \beta$-mannanase (Hemicell $^{\mathrm{TM}}$ HT-D, Elanco Animal Health, Guelph, ON, Canada; endo-1,4- $\beta$-mannanase $\left(160 \times 10^{6}\right.$ units $\left./ \mathrm{kg}\right)$ from Paenibacillus alvei). The third treatment was challenged with repeated LPS immune system stimulation (ISS) and received the same diet as ENZ. This treatment design was determined based on the hypothesis, supported by previous research, that $\beta$-mannanase would inhibit a FIIR if it 
Table 1 Summary of experimental treatments

\begin{tabular}{llll}
\hline & Experimental treatment & & \\
\cline { 2 - 4 } & CON $^{a}$ & ENZ $^{\mathrm{b}}$ & ISS $^{\mathrm{c}}$ \\
\hline Diet & Control & Control + $\beta$-Mannanase & Control + $\beta$-Mannanase \\
B-mannanase inclusion & No & Yes & Yes \\
Challenge treatment & Saline & Saline & E. coli LPS \\
\hline
\end{tabular}

${ }^{a}$ Control treatment $(\mathrm{CON})=$ pigs fed basal diet with no LPS (Escherichia coli serotype O55:B5) injection

${ }^{\mathrm{b}}$ Enzyme treatment $(E N Z)=$ pigs fed enzyme diet $(0.056 \% \beta$-mannanase $)$ with no LPS injection

Immune system stimulation treatment (ISS) = pigs fed enzyme diet $(0.056 \% \beta$-mannanase) with LPS injection

occurred in CON $[6,7]$. In this way, the effect of an innate immune stimulation by LPS could be evaluated independent of a FIIR.

Upon arrival and during the pre-trial period, pigs were housed individually in pens $(1.83 \mathrm{~m} \times 1.22 \mathrm{~m})$ with plastic-covered expanded metal flooring in a temperature-controlled room $\left(26 \pm 2{ }^{\circ} \mathrm{C}\right)$. Daily feed allotment during the pre-trial period was adjusted based on BW measured every $4 \mathrm{~d}$. Pigs were maintained on the pre-trial diet for at least $4 \mathrm{~d}$ until initiation of the experiment for their respective block, at which time pigs received their assigned treatment diets. The experiment consisted of a 10- $\mathrm{d}$ adaptation phase, a 5-d total feces and urine collection phase, and $34 \mathrm{~h}$ of heat production (HP) measurements.

At trial initiation (d 1), pigs were individually housed in adjustable metabolism crates $(1.80 \mathrm{~m} \times 0.60 \mathrm{~m})$ with smooth transparent plastic sides and plastic-covered expanded metal flooring in a temperature controlled room $\left(26 \pm 2{ }^{\circ} \mathrm{C}\right)$. Body weight was measured on $\mathrm{d} 1,5,10,16$, daily feed allotment was adjusted accordingly, and pigs were trained to consume the entire meal within $1 \mathrm{~h}$ of feeding at 08:00 h. Orts, if any, were measured to accurately determine average daily feed intake (ADFI).

\section{Immune challenge}

A low dose, repeated LPS challenge, following the modified procedures described by Rakhshandeh and de Lange [8], was chosen to induce an inflammatory response representative of sustained immune system stimulation in the ISS treatment. The challenge consisted of four repeated low-dose injections of Escherichia coli LPS serotype O55:B5 (Sigma-Aldrich, St. Louis, MO, USA) for pigs on treatment ISS, or a control injection of sterile saline for pigs in treatments CON and ENZ. The LPS was dissolved in sterile PBS so that an injection of $0.1 \mathrm{~mL} / \mathrm{kg}$ of BW achieved the desired dosage [13].

A pilot study with 12 pigs was conducted prior to experiment initiation to discern the lowest appropriate initial LPS dose and the subsequent dose increase regimen required to limit LPS tolerance development. Results of the pilot study (not reported herein) indicated that an initial dose of $20 \mu \mathrm{g} \mathrm{LPS} / \mathrm{kg}$ of BW with subsequent dose increases of $20 \%, 30 \%$, and $40 \%$ was the regimen that maintained a febrile response (rectal temperature $\geq$ $40{ }^{\circ} \mathrm{C}$ ) at all four challenges while minimizing anorexia and vomiting.

During the main experiment, pigs were injected intramuscularly at 10:00 h on d 10,12,14, and 16 with either sterile saline or LPS, following the previously described dosing regimen determined from the pilot study. Baseline rectal temperature was measured on d 5 and 8 at 14:00 h and at $4 \mathrm{~h}$ post-challenge (14:00 h) on d 10, 12, and 14 . Blood samples were then collected on d 8 (pre-challenge) and $\mathrm{d} 10$ (post-challenge) via jugular venipuncture into two 10-mL tubes for EDTA-whole blood and serum. Whole blood samples were placed on ice pending transportation to the laboratory for complete blood count $(\mathrm{CBC})$ analysis with white blood cell (WBC) manual differential. Serum was separated by centrifugation $(2,000 \times g$ for $15 \mathrm{~min}$ at $4{ }^{\circ} \mathrm{C}$ ), collected and divided into three subsamples, and stored at $-80^{\circ} \mathrm{C}$ until analyzed.

\section{Digestibility}

On d 10, pigs received $5 \mathrm{~g}$ of ferric oxide as an indigestible marker mixed with $100 \mathrm{~g}$ of feed; the remaining allotted feed was offered after the marked feed was consumed. Fecal collection commenced when the marker first appeared in the feces. On d 15, pigs were offered $100 \mathrm{~g}$ of marked feed as previously described, and fecal collection terminated when the marker appeared in the feces. Feces were weighed and stored at $-20{ }^{\circ} \mathrm{C}$ until further processing. Total urine collection commenced at 08:00 h on $\mathrm{d} 11$ and terminated at 08:00 h on d 16. Urine was collected once daily into jugs containing $10 \mathrm{~mL}$ of $6 \mathrm{~mol} / \mathrm{L} \mathrm{HCl}$. Urine was weighed, thoroughly mixed and subsampled (10\% of urine weight), strained through glass wool, and stored at $-20{ }^{\circ} \mathrm{C}$. Urine subsamples were pooled per pig throughout the collection period.

\section{Heat production}

On d 16, within 30 min of consuming their daily feed allotment, pigs were transferred to open-circuit indirect calorimetry chambers $(1.22 \mathrm{~m} \times 0.61 \mathrm{~m} \times 0.91 \mathrm{~m}$ metallic box with a glass door on the front side, plastic-covered expanded metal sheet flooring, and a valve at the bottom to collect urine; Columbus Instruments, Columbus, $\mathrm{OH}$, USA) for $34 \mathrm{~h}$ of calorimetric measurements. Pigs were 
Table 2 Experimental diet ingredient and analyzed nutrient composition (as-fed basis)

\begin{tabular}{|c|c|c|}
\hline Item & Control diet & Enzyme diet \\
\hline \multicolumn{3}{|l|}{ Ingredient, $\%$ of diet } \\
\hline Corn & 47.33 & 47.27 \\
\hline $\begin{array}{l}\text { Soybean meal, (dehulled, } \\
\text { solvent extracted) }\end{array}$ & 38.40 & 38.40 \\
\hline Soybean hulls & 10.00 & 10.00 \\
\hline Soybean oil & 1.85 & 1.85 \\
\hline Limestone & 1.04 & 1.04 \\
\hline Monocalcium phosphate & 0.60 & 0.60 \\
\hline Vitamin premix ${ }^{\mathrm{a}}$ & 0.33 & 0.33 \\
\hline Trace mineral premix ${ }^{\mathrm{b}}$ & 0.20 & 0.20 \\
\hline Salt & 0.25 & 0.25 \\
\hline Hemicell HT-D ${ }^{c}$ & 0.00 & 0.06 \\
\hline \multicolumn{3}{|l|}{ Calculated composition, \% of diet } \\
\hline SID Lys & 1.18 & 1.18 \\
\hline SID Met & 0.32 & 0.32 \\
\hline SID Thr & 0.75 & 0.75 \\
\hline SID Trp & 0.26 & 0.26 \\
\hline SID Cys + Met & 0.62 & 0.62 \\
\hline$\beta$-mannan ${ }^{e}$ & 1.33 & 1.33 \\
\hline \multicolumn{3}{|l|}{ Analyzed composition, \% of diet } \\
\hline DM & 86.75 & 87.17 \\
\hline GE, Mcal/kg & 4.03 & 4.00 \\
\hline $\mathrm{CP}$ & 22.28 & 21.83 \\
\hline$E E^{d}$ & 4.02 & 3.97 \\
\hline Starch & 29.34 & 30.89 \\
\hline NDF & 12.17 & 11.83 \\
\hline ADF & 6.97 & 6.79 \\
\hline endo-1,4- $\beta$-mannanase, I IU/kg & Below detectable limit ${ }^{9}$ & 150,000 \\
\hline
\end{tabular}

aProvided per kilogram of complete diet: 6,614 IU of vitamin A; 827 IU of vitamin D; 26 IU of vitamin E; $2.6 \mathrm{mg}$ of vitamin K; $29.8 \mathrm{mg}$ of niacin; $16.5 \mathrm{mg}$ of pantothenic acid; $5.0 \mathrm{mg}$ of riboflavin; $0.023 \mathrm{mg}$ of vitamin $\mathrm{B}_{12}$

bProvided per kilogram of complete diet: $\mathrm{Zn}, 165 \mathrm{mg}$ as $\mathrm{ZnSO}_{4} ; \mathrm{Fe}_{1}, 165 \mathrm{mg}$ as $\mathrm{FeSO}_{4} ; \mathrm{Mn}, 39 \mathrm{mg}$ as $\mathrm{MnSO}_{4} ; \mathrm{Cu}, 17 \mathrm{mg}$ as $\mathrm{CuSO}_{4} ; \mathrm{I}, 0.3 \mathrm{mg}$ as $\mathrm{Ca}\left(\mathrm{IO}_{3}\right)_{2}$; and $\mathrm{Se}, 0.3 \mathrm{mg}$ as $\mathrm{Na}_{2} \mathrm{SeO}_{3}$

${ }^{\mathrm{C}}$ Hemicell ${ }^{\mathrm{TM}} \mathrm{HT}$-D, Elanco Animal Health, Guelph, ON, Canada; endo-1,4- $\beta$-mannanase $\left(160 \times 10^{6}\right.$ units $\left./ \mathrm{kg}\right)$ from Paenibacillus alvei

${ }^{\mathrm{d} A c i d}$ hydrolyzed ether extract

${ }^{\mathrm{e}} \beta$-mannan concentration was calculated using values reported in Shastak et al. [70]

fendo-1,4- $\beta$-mannanase activity. $1 \mathrm{IU}=$ the amount of enzyme which generates 0.72 micrograms of reducing sugars per minute from a mannose-containing substrate at $\mathrm{pH} 7.0$ and temperature of $40{ }^{\circ} \mathrm{C}$

${ }^{9}$ The lowest detectable limit was $15,000 \mathrm{IU} / \mathrm{kg}$

randomly assigned to chambers to reduce the possibility of a chamber bias. The first $2 \mathrm{~h}$ of HP (08:00-10:00 h), measured prior to pigs receiving the fourth and final challenge of either LPS or saline, were designated as acclimation and not included in HP calculations. Total oxygen consumption $\left(\mathrm{VO}_{2}\right)$ and carbon dioxide production $\left(\mathrm{VCO}_{2}\right)$ were measured every 12 min corresponding to 170 values over $34 \mathrm{~h}$. The first $24 \mathrm{~h}$ following feeding was designated as the fed state and the last $12 \mathrm{~h}$ as the fasting state $[14,15]$. Urine voided during the fed and fasting periods was collected separately and processed as previously described. Personnel movement within the room was minimized during HP measurement to avoid any disturbance of the pigs. The system was validated using the alcohol combustion method described by Aulick et al. [16] and the $\mathrm{O}_{2}$ and $\mathrm{CO}_{2}$ sensors were calibrated prior to each block of the experiment. The chambers were air-conditioned to maintain a constant temperature $\left(23 \pm 1{ }^{\circ} \mathrm{C}\right)$. Pig BW on d 16 was similar across all treatments $(14.1 \pm 0.3 \mathrm{~kg})$. Heat production was measured in only seven of the ten experimental blocks because of equipment failure during three blocks; therefore, for HP data, $n=7$.

\section{Analytical methods}

All diet, orts, and fecal samples were dried at $60{ }^{\circ} \mathrm{C}$ to a constant weight and were ground to a particle size of $1 \mathrm{~mm}$. Urine samples were thawed, sieved through cotton gauze, and filtered with glass wool. Urine, diet, and fecal samples were analyzed in duplicate for nitrogen $(\mathrm{N}$; method 990.03 [17]; TruMac'; LECO Corp., St. Joseph, MI, USA). An EDTA sample $(9.56 \% \mathrm{~N})$ was used as the standard for calibration and was determined to be $(9.55$ $\pm 0.01) \% \mathrm{~N}$. Crude protein $(\mathrm{CP})$ was calculated as $\mathrm{N} \times$ 6.25. Diets were analyzed for mannan (Galactomannan Assay Kit, Megazyme International, Wicklow, Ireland) and $\beta$-mannanase concentration (colorimetric determination, Elanco Animal Health, Gaithersburg, MD).

Diet and fecal samples were analyzed in duplicate for dry matter (DM; method 930.15), acid hydrolyzed ether extract (EE; method 2003.06), and starch (Total Starch Assay Kit, Megazyme International, Wicklow, Ireland, method 996.11) using standard methods [17]; and in triplicate for neutral and acid detergent fiber components (NDF [18] and ADF [19], respectively). Hemicellulose was calculated as the difference between NDF and ADF concentrations. Gross energy (GE) was determined using a bomb calorimeter (model 6200; Parr Instrument Co., Moline, IL). Benzoic acid (6,318 kcal GE/kg; Parr Instrument Co.) was used as the standard for calibration and was determined to contain $6,325 \pm 6.9 \mathrm{kcal} \mathrm{GE} / \mathrm{kg}$. Urine GE was calculated as 192 plus 31 times the concentration of urinary $\mathrm{N}$ [20] and multiplied by a factor of 0.239 to convert the unit to kcal.

Pre- and post-challenge whole blood samples and blood smears were analyzed for CBC performed by Manitoba Veterinary Diagnostic Services (Winnipeg, MB, Canada) using Advia 2120i (Siemens Healthcare Diagnostics, Tarrytown, NY, USA) with a manual differential. The main response variables of interest were total cell, $\mathrm{RBC}$, and WBC (mature and immature neutrophils, 
eosinophils, basophils, lymphocytes, and monocytes) concentrations.

Serum was divided into three subsamples. One set was analyzed for glucose and insulin concentrations by Animal Health Laboratory (University of Guelph, ON, Canada). Glucose concentration was determined on an automated Roche Cobas C501 analyzer (GLUC3 application, Roche Diagnostics, Indianapolis, IN, USA) and insulin concentration was quantified using commercial RIA kits (PI-12 K, EMD Millipore, Billerica, MA, USA). The second serum subset was analyzed for cytokine concentrations (granulocyte macrophage colony-stimulating factor (GM-CSF), tumor necrosis factor alpha (TNF $)$, Interleukin (IL)-one-alpha (IL-1 $\alpha), \quad$ IL-1 $\beta$, IL-one-receptor antagonist (IL-1ra), IL-2, IL-4, IL-6, IL-8, IL-10, IL-12, and IL-18) by a commercial multiplex assay using laser bead technology (Eve Technologies, Calgary, AB, Canada). The third serum set was analyzed for concentration of APPs haptoglobin and mannose-binding lectin A (MBL) using porcine-specific commercial ELISA kits (Immunology Consultants Laboratory, Inc., Portland, OR, USA; MyBioSource, Inc., San Diego, CA, USA, respectively).

\section{Calculations}

Dry matter, GE, CP, EE, starch, hemicellulose, NDF, and ADF apparent total tract digestibility (ATTD; \%) were calculated on a DM basis as [(nutrient intake - nutrient output in feces)/nutrient intake] $\times 100$. Digestible energy (DE) content of the diet was calculated as $\mathrm{GE} \times \mathrm{GE}$ ATTD. Dietary ME was calculated according to the equation of Noblet et al. [21]: $\mathrm{ME}=\mathrm{DE}-$ [urine GE + (0.4\% of DE intake)]. Nitrogen retention (NR) was calculated by the difference between $\mathrm{N}$ intake and $\mathrm{N}$ excreted in the feces and urine, and protein deposition (PD) was determined as NR $\times 6.25$.

Heat production was calculated from respiratory gas exchanges and urinary $\mathrm{N}$ production according to the equation of Brouwer [22]: $\mathrm{HP}(\mathrm{kcal})=3.87 \times \mathrm{VO}_{2}$ consumed $(\mathrm{L})+1.20 \times \mathrm{VCO}_{2}$ produced $(\mathrm{L})-1.43 \times$ urinary $\mathrm{N}$ production (g). Methane production was not accounted for, but has been estimated to be very low in growing pigs $(<1 \%$ [23]). All HP parameters were normalized to a period of $24 \mathrm{~h}$, expressed as kcal of heat produced per $\mathrm{kg}$ of $\mathrm{BW}^{0.60}$ [24] and per $\mathrm{kg}$ of DM intake (DMI) in order to remove known effects of variations in BW and DMI $[25,26]$.

Total heat production $\left(\mathrm{HP}_{\text {total }}\right)$ was the average $\mathrm{HP}$ during the $22 \mathrm{~h}$ of post-challenge, fed state measurement. Total fasting heat production $\left(\mathrm{FHP}_{\text {total }}\right)$ was the average HP over the $12 \mathrm{~h}$ fasted-state. Because the system was not equipped to quantify and separate HP due to physical activity, fasting heat production (FHP) was derived from the 10 lowest HP values over the fasted-state, reflecting energy metabolism due to basal metabolic rate and not associated with feed consumption, digestion, or physical activity [27, 28]. The respiratory quotient (RQ) was calculated as $\mathrm{VCO}_{2}$ divided by $\mathrm{VO}_{2}$ during the fed $\left(\mathrm{RQ}_{\mathrm{fed}}\right)$ and fasting $\left(\mathrm{RQ}_{\text {fast }}\right)$ states.

To best estimate components of HP not attributed to the basal metabolic rate, HP values for physical activity and the thermic effect of feeding (TEF) were calculated. Activity heat production (AHP) was estimated utilizing fed-state HP data measured over $10 \mathrm{~h}$ post-challenge to represent normal post-feeding daytime behavior. The difference between the average HP over this $10 \mathrm{~h}$ period $\left(\mathrm{HP}_{10}\right)$ and the average of the 10 lowest $\mathrm{HP}$ values over the same time $\left(\mathrm{HP}_{\text {low; }}\right.$; representative of sedentary, resting behavior; $[27,28])$ was designated as AHP. The TEF was calculated as the difference between $\mathrm{HP}_{10}$ and the sum of AHP and FHP, so that any HP in excess of basal metabolism and activity was partitioned toward TEF. Heat increment $(\mathrm{HI})$ was then calculated as the sum of AHP and TEF. Using these data, the efficiency of utilizing $\mathrm{ME}$ for maintenance and growth $\left(\mathrm{k}_{\mathrm{mg}}, \%\right)$ was calculated as $(1-\mathrm{HI} / \mathrm{ME}$ intake $) \times 100[25,29]$. To address the primary research question of how an immune challenge and $\beta$-mannanase supplementation impact maintenance energy requirements, metabolizable energy used for maintenance $\left(\mathrm{ME}_{\mathrm{m}}\right)$ was then calculated as FHP $\times$ $100 / \mathrm{k}_{\mathrm{mg}}[25,29]$.

Together, dietary energy, $\mathrm{N}$ balance, and HP values were utilized to characterize energy use and balance in the pig. Retained energy (RE) was calculated by the difference of ME intake and the total HP during the $24 \mathrm{~h}$ fed-state (both pre- and post-challenge) to account for all energy not available for tissue accretion [29]. Energy retained as protein $\left(R E_{p}\right)$ was calculated from $\mathrm{N}$ balance assuming a PD (g) energy value of $5.64 \mathrm{kcal} / \mathrm{g}$ [30]. Energy retained as lipid $\left(\mathrm{RE}_{\mathrm{l}}\right)$ was calculated as the difference between $R E$ and $R E_{p}$ [30]. Lipid deposition (LD) was then determined from $\mathrm{RE}_{1}$ assuming an energy content of $9.49 \mathrm{kcal} / \mathrm{g}$ of deposited lipid [22]. Dietary net energy $(\mathrm{NE} ; \mathrm{kcal} / \mathrm{kg}$ ) was calculated as the sum of RE and FHP divided by DMI [21].

\section{Statistical analyses}

Data were analyzed as a randomized complete block design with pig as the experimental unit. The UNIVARIATE procedure of SAS (Version 9.4, SAS Inst., Cary, $\mathrm{NC}$ ) was used to verify normality and homogeneity of variances. Statistical outliers (>3 SD away from the mean) were removed; therefore, one pig from the ISS treatment was removed from HP data because of poor feed intake on the day of HP measurement. Immature neutrophil, eosinophil, and basophil $\mathrm{CBC}$ data were log transformed to achieve a normal distribution.

The main effects of dietary treatment and block were analyzed using the MIXED procedure of SAS. The 
staggered block experimental design resulted in variations in time and body weight among blocks. This variation was expected and resulted in statistical detection of block as a significant main effect in most response variables. Therefore, block remained in the statistical model, but block $P$-values are not reported herein.

Differences among treatments were determined using ANOVA and means were separated using the least square means statement and the PDIFF option. Immune and rectal temperature data were analyzed as repeated measures and covariance structures resulting in the lowest AIC values for each variable were applied. To further evaluate $\beta$-mannanase effects on immune parameters pre-challenge, contrasts comparing CON versus ENZ and ISS values were generated using the contrast statement of the MIXED procedure. Differences were considered significant if $P$ was $\leq 0.05$ and a trend if $P$ was $>0.05$ and $\leq 0.10$.

\section{Results}

Immune response parameters Immune system stimulation effects

Pigs on the ISS treatment exhibited minimal vomiting, diarrhea and signs of lethargy and hyperventilation after the first and to a lesser extent, the second LPS injection. After the third and fourth challenges, ISS pigs continued to demonstrate signs of lethargy and hyperventilation, but vomiting and diarrhea were not observed. No pigs died after any injection. The immune stimulation model successfully induced a sustained febrile response (rectal temperature $\geq 40^{\circ} \mathrm{C}$ ) in ISS pigs on d 10,12 , and 14 (treatment by day interaction $P<0.0001$; Fig. 1). Pigs in CON and ENZ treatments maintained normal rectal temperatures $\left(38.85{ }^{\circ} \mathrm{C} \pm 0.15\right)$ throughout the experiment.

There was a significant interaction between the effects of time (pre- or post-challenge) and treatment on WBC, mature neutrophil, lymphocyte, and monocyte counts and a trend for an interaction on RBC count (Additional file 2: Table S2). In all four variables, treatments had similar cell counts at the pre-challenge time point $(P \geq 0.10)$. Post-challenge, immune stimulation by LPS decreased WBC, mature neutrophil, lymphocyte, and monocyte counts compared to CON and ENZ ( $P \leq 0.05$; Fig. 2). There were no differences among treatments or time periods for total cell, immature neutrophil, eosinophil, or basophil counts $(P>0.10$; Additional file 2: Table S2).

Glucose, insulin, haptoglobin, and MBL serum concentrations were not affected by the interaction of time and treatment $(P>0.10)$, but concentrations were higher pre-challenge compared to post-challenge for glucose, haptoglobin, and MBL (Additional file 3: Table S3).

Lipopolysaccharide challenge increased IL-1 $\beta$, IL-1ra, IL-6, IL-8, and TNF $\alpha$ concentrations post-challenge compared to ISS pre-challenge and both pre- and post-challenge concentrations in CON and ISS (Fig. 3). All other cytokines were not significantly impacted by the interaction or main effects of time and treatment $(P>0.10$; Additional file 3: Table S3). Interferon-gamma was not detected in any of the samples. Serum GM-CSF concentrations were not different $(P>0.10)$ among CON and ENZ pre-and post-challenge and ISS pre-challenge, while ISS post-challenge GM-CSF concentration was increased compared to the ISS pre-challenge value and CON and ENZ post-challenge values $(P \leq 0.015$; Fig. 3$)$.

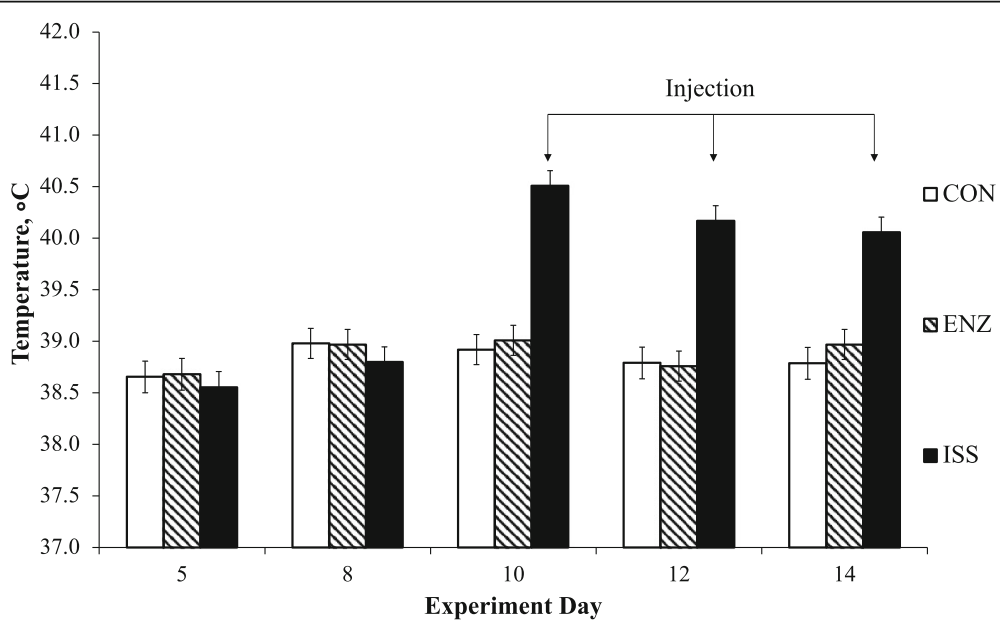

Fig. 1 Effect of treatment on young weaned pig $\left(n=10\right.$ per treatment) rectal temperature $\left({ }^{\circ} \mathrm{C}\right)$. Control treatment $(\mathrm{CON})=$ pigs fed basal diet (0.0\% $\beta$-mannanase) with saline injection. Enzyme treatment $(E N Z)=$ pigs fed enzyme diet $(0.056 \% \beta$-mannanase) with saline injection. Immune system stimulation treatment (ISS) = pigs fed enzyme diet (0.056\% $\beta$-mannanase) with LPS (Escherichia coli serotype O55:B5) injection. The arrows indicate days on which either a saline (CON and ENZ) or LPS (ISS) injection were administered at 10:00 $\mathrm{h}$. Rectal temperatures were measured $4 \mathrm{~h}$ post-challenge. Data points on $\mathrm{d} 5$ and 8 represent average baseline pre-challenge temperature, and $\mathrm{d} 10,12$, and 14 represent post-challenge temperatures. Treatment by day interaction $P<0.0001$; day $P<0.0001$; treatment $P<0.0001$; block $P=0.0015$ 


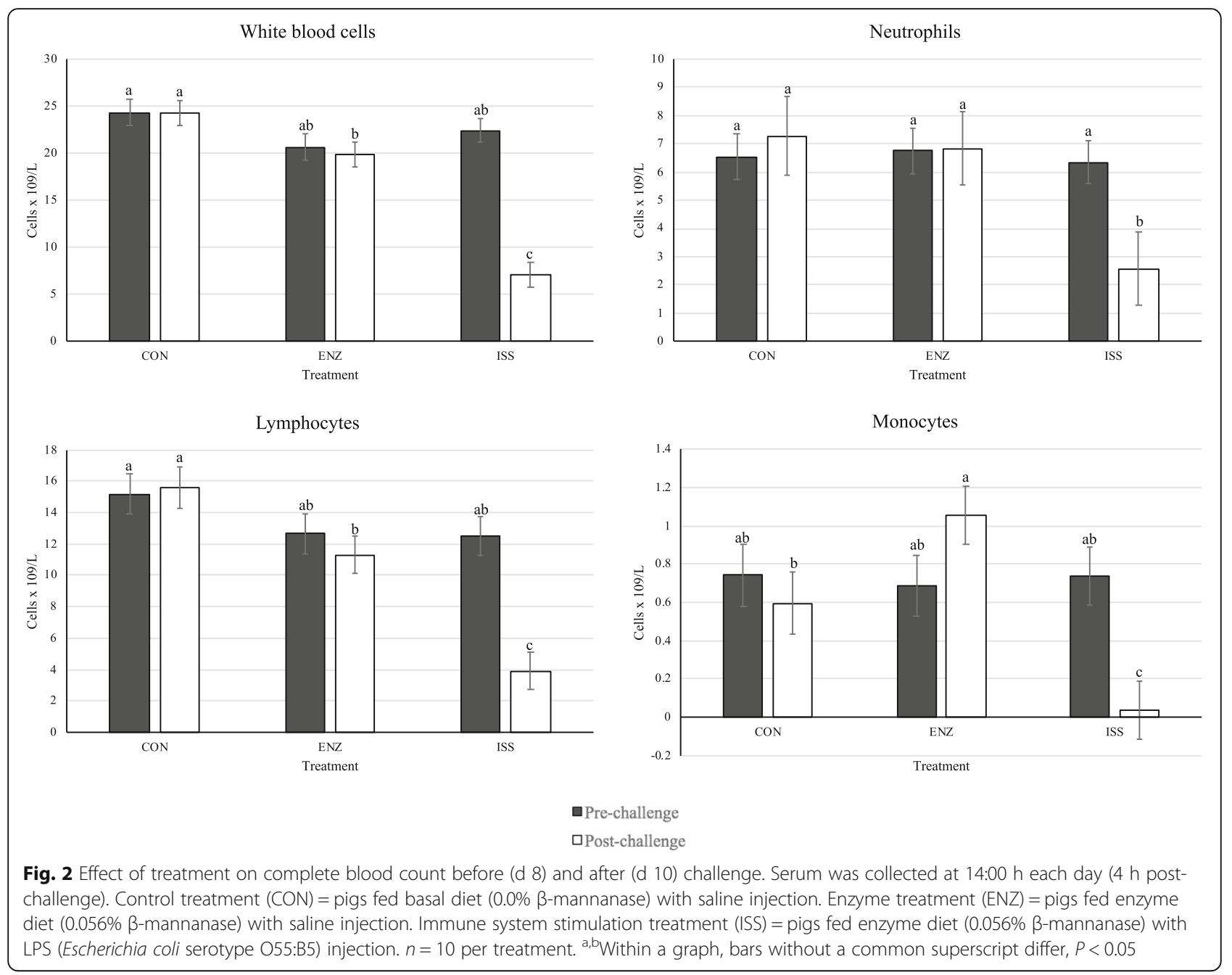

\section{$\beta$-mannanase effects}

Contrasts comparing immune cell dynamics of pigs fed either the control or $\beta$-mannanase diet prior to the first challenge on $\mathrm{d} 10$ detected no differences in $\mathrm{CBC}$ values $(P \geq 0.10$; Table 3$)$. Similarly, serum glucose, insulin, MBL, and cytokine concentrations (except IL-1 $\alpha$ ) did not differ because of $\beta$-mannanase supplementation $(P \geq 0.230$; Table 4). Serum haptoglobin and IL- $1 \alpha$ concentrations were decreased in diets supplemented with $\beta$-mannanase $(P \leq 0.05$; Table 4$)$.

\section{Pig growth performance, nitrogen balance, and diet digestibility}

Average initial BW was $10.27 \pm 0.15 \mathrm{~kg}$, d 16 average $B W$ was $15.12 \pm 0.27 \mathrm{~kg}$, and BW did not differ among treatments at either time point $(P \geq 0.471)$. Average daily gain (ADG) over the entire 16-d experiment was not different among treatments $(P=0.13$; Table 5$)$, but ISS ADG during the immune challenge (d 10-16) was less than CON and ENZ gain $(P=0.010$; Table 7).
Immune system simulation numerically decreased ADFI and thus $\mathrm{N}$ intake compared to CON and ENZ $(P=$ $0.021)$, resulting in decreased fecal $\mathrm{N}$ excretion on a $\mathrm{g}$ per $\mathrm{d}$ basis $(P=0.007)$. Urine $\mathrm{N}$ excretion during the challenge period was similar among treatments $(P=0.045)$, but retained $\mathrm{N}$ in the ISS treatment was less than that of CON, with ENZ being intermediate $(P=0.045$; Table 5$)$. Partitioning of excreted $\mathrm{N}$ to either the feces or urine was not different among treatment $(P=0.78)$. When $\mathrm{N}$ excretion was expressed as a percent of $\mathrm{N}$ intake, the previously observed significant treatment effect on fecal $\mathrm{N}$ excretion was no longer evident (Table 5). There were no differences among treatments in ATTD of any analyzed nutrient $(P \geq$ 0.120; Table 6) and all ATTD coefficients were within normal ranges for 10 to $15 \mathrm{~kg}$ pigs.

Heat production, maintenance energy requirements, and energy retention

Day $16 \mathrm{ME}$ intake was similar among treatments $\left(759.4 \pm 37.7 \mathrm{kcal} / \mathrm{kg} \mathrm{BW}{ }^{0.60} / \mathrm{kg} \mathrm{DMI} / \mathrm{d} ; P=0.92\right)$. Immune system stimulation increased fed state $\mathrm{HP}_{\text {total }}$ 


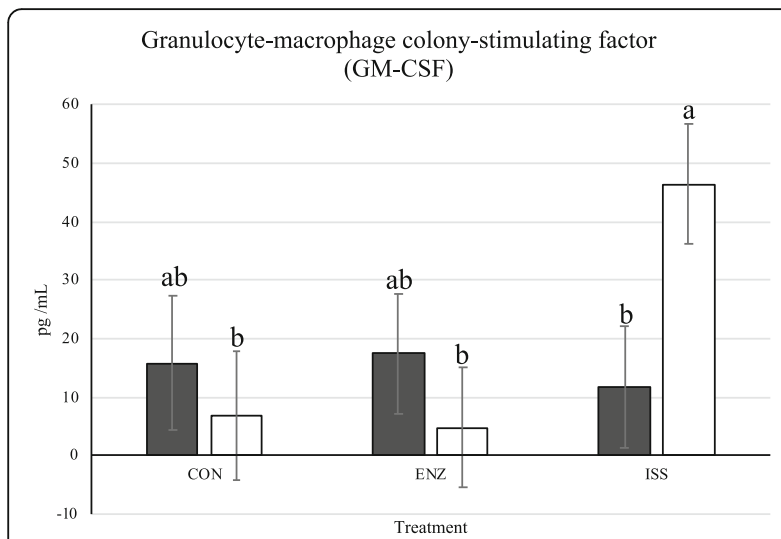

Interleukin-1 $\beta(\mathrm{IL}-1 \beta)$
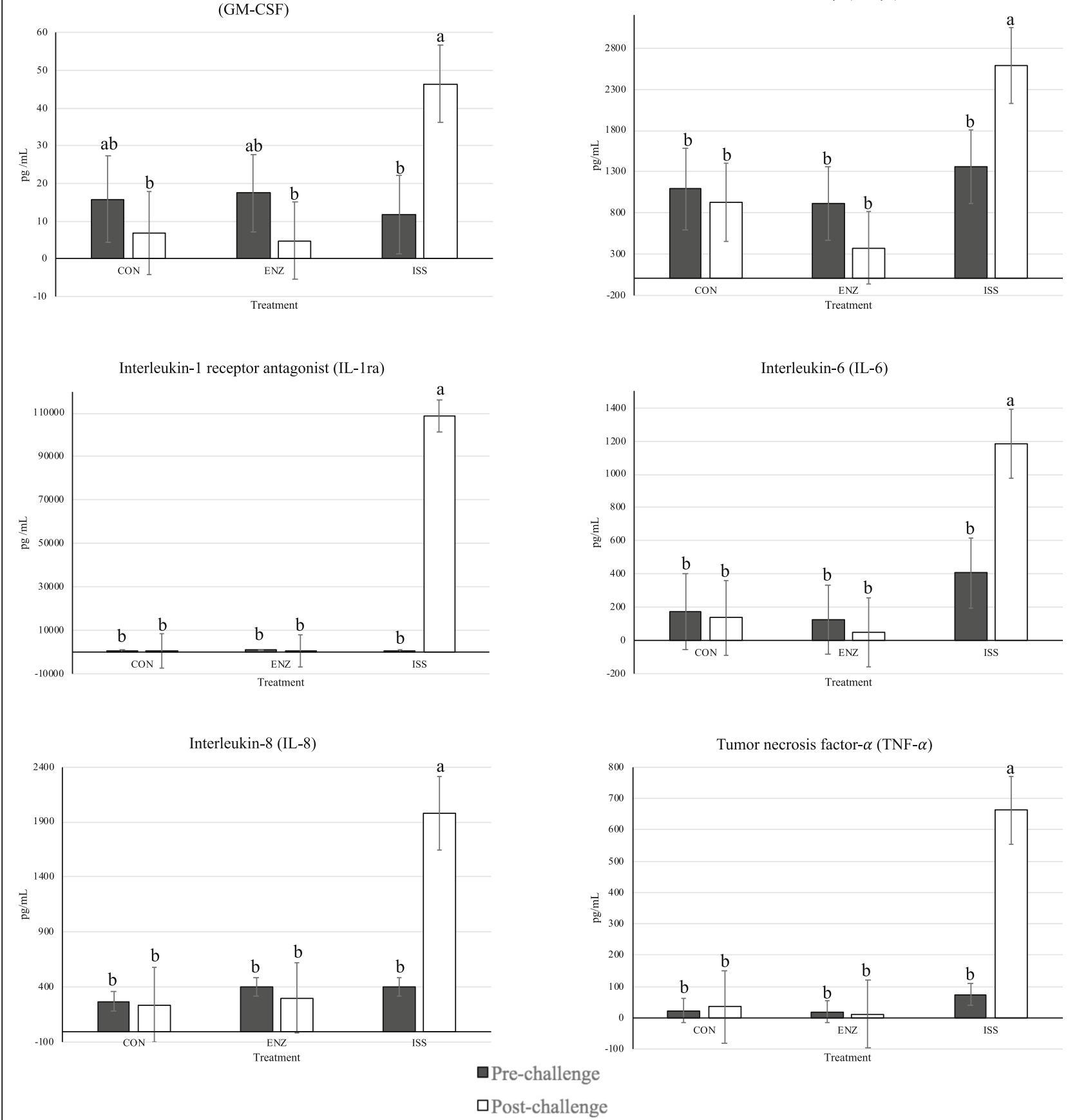

Fig. 3 Effect of treatment on serum cytokine concentrations before ( $\mathrm{d}$ 8) and after ( $\mathrm{d}$ 10) challenge. Serum was collected at 14:00 h each day (4 h post- challenge). Control treatment $(\mathrm{CON})=$ pigs fed basal diet $(0.0 \% \beta$-mannanase) with saline injection. Enzyme treatment (ENZ) $=$ pigs fed enzyme diet $(0.056 \% \beta$-mannanase) with saline injection. Immune system stimulation treatment (ISS) = pigs fed enzyme diet $(0.056 \% \beta$-mannanase) with LPS (Escherichia coli serotype O55:B5) injection. $n=10$ per treatment. ${ }^{a, b}$ Within a graph, bars without a common superscript differ, $P<0.05$

compared to CON and ENZ $(P=0.040 ;$ Table 7$)$. In the fasting state, neither immune stimulation nor $\beta$-mannanase supplementation affected $\mathrm{FHP}_{\text {total }}$ or FHP compared to control $(P \geq 0.135)$. Treatment did not affect $\mathrm{RQ}$ in the fed and fasting states $(P \geq 0.23$; Table 7).
Immune system stimulation increased $\mathrm{ME}_{\mathrm{m}}(\mathrm{kcal} / \mathrm{kg}$ $\mathrm{BW}^{0.60} / \mathrm{kg}$ DMI $\left./ \mathrm{d}\right)$ compared to CON or ENZ pigs $(P=0.045)$, but $\mathrm{k}_{\mathrm{mg}}$ among treatments did not differ $(P=0.13$; Table 7$)$. When $\mathrm{ME}_{\mathrm{m}}$ was expressed as $\mathrm{kcal} / \mathrm{d}$, the significant treatment effect was no longer detected $(P=0.90)$. Beta-mannanase supplementation 
Table 3 Complete blood count values in young weaned pigs fed a diet with or without $\beta$-mannanase $e^{a, b}$

\begin{tabular}{|c|c|c|c|c|c|}
\hline \multirow[t]{2}{*}{ Treatment } & \multicolumn{2}{|c|}{ Control diet ${ }^{c}$} & \multicolumn{2}{|c|}{$\beta$-mannanase diet ${ }^{d}$} & \multirow{2}{*}{$\begin{array}{l}\text { Contrast } \\
P \text {-value }\end{array}$} \\
\hline & Estimate & SEM & Estimate & SEM & \\
\hline \multicolumn{6}{|c|}{ Cell type count, cells $\times 10^{9} / \mathrm{L}^{\mathrm{e}}$} \\
\hline Total cells & 468.6 & 34.9 & 432.4 & 23.8 & 0.405 \\
\hline WBC & 24.50 & 1.43 & 21.51 & 0.98 & 0.104 \\
\hline Neut & 6.47 & 0.94 & 6.83 & 0.64 & 0.758 \\
\hline Bands & 0.200 & 0.050 & 0.266 & 0.034 & 0.504 \\
\hline Eos & 0.202 & 0.099 & 0.300 & 0.068 & 0.599 \\
\hline Baso & 0.048 & 0.061 & 0.100 & 0.042 & 0.451 \\
\hline Lymph & 15.35 & 1.46 & 12.46 & 1.00 & 0.124 \\
\hline Mono & 0.727 & 0.181 & 0.709 & 0.123 & 0.934 \\
\hline RBC & 7.44 & 0.14 & 7.55 & 0.09 & 0.547 \\
\hline
\end{tabular}

${ }^{\mathrm{a}}$ Blood was collected on $\mathrm{d} 8$ of the experiment $6 \mathrm{~h}$ post-feeding, prior to the immune challenge beginning on $\mathrm{d} 10$

${ }^{\mathrm{b}} n=10$ pigs per treatment

${ }^{\mathrm{C} C o n t r o l ~ d i e t ~ w a s ~ a ~ c o r n, ~ s o y b e a n ~ m e a n, ~ a n d ~ s o y ~ h u l l s ~ b a s e d ~ d i e t ~ c o n t a i n i n g ~}$

$1.33 \% \beta$-mannans, and did not contain $\beta$-mannanase enzyme. Pigs on the control $(\mathrm{CON})$ treatment were fed the control diet and estimates are representative of the $\mathrm{CON}$ treatment only

${ }^{d}$ Enzyme diet was the control diet supplemented with $0.056 \% \beta$-mannanase (Hemicell $^{\mathrm{TM}}$ HT-D, Elanco Animal Health, Guelph, ON, Canada; endo-1,4- $\beta$ mannanase $\left(160 \times 10^{6}\right.$ units $\left./ \mathrm{kg}\right)$ from Paenibacillus alvei). Pigs on the enzyme (ENZ) and immune system stimulation (ISS) treatments were fed the enzyme diet. Estimates are representative of the ENZ and ISS treatments prior to immune stimulation

${ }^{\text {e}}$ Basophils (Baso); eosinophils (Eos); immature neutrophils (Bands); lymphocytes (Lymph); mature neutrophils (Neut); monocytes (Mono); white blood cells (WBC)

did not change $M E_{m}$ relative to CON whether expressed as $\mathrm{kcal} / \mathrm{kg} \mathrm{BW}^{0.60} / \mathrm{kg} \quad \mathrm{DMI} / \mathrm{d} \quad(P=0.98)$, $\mathrm{kcal} / \mathrm{kg} \mathrm{BW} / \mathrm{d}(P=0.72)$, or $\mathrm{kcal} / \mathrm{d}(P=0.77)$.

Absorbed energy not lost via urine, gases, heat increment, activity and TEF, or maintenance, is retained as either protein or lipid. Immune system stimulation decreased $\mathrm{RE}_{1}$ compared to $\mathrm{CON}$ and ENZ $(P=0.046)$ but $\mathrm{RE}_{\mathrm{p}}$ and total RE were not different among treatments $(P>0.32)$ when expressed as $\mathrm{kcal} / \mathrm{kg} \mathrm{BW} \mathrm{BW}^{0.60} / \mathrm{kg} \mathrm{DMI} / \mathrm{d}$ (Table 7 ). When RE was expressed as a proportion of ME intake, similar treatment effects were observed for $R E_{1}$ and $R E_{p}$, but a significant decrease in total $R E$ was detected due to ISS $(P=0.033$; Table 7$)$. As less energy was retained as lipid, LD was decreased in the ISS treatment compared to $\mathrm{CON}$ and $\mathrm{ENZ}(P=0.047)$ while no differences were observed in PD $(P=0.15$; Table 7$)$.

\section{Dietary energy values and efficiency}

The ENZ and ISS treatments tended to decrease diet DE and ME values relative to $\mathrm{CON}(P \leq 0.052$; Table 8$)$. Neither ISS nor $\beta$-mannanase supplementation (ENZ treatment) affected dietary $\mathrm{NE}$ value $(P=0.75)$ or $\mathrm{ME}$ and NE efficiency $(P \geq 0.46)$.
Table 4 Effect of $\beta$-mannanase on pig serum glucose, insulin, acute phase protein, and cytokine concentrations ${ }^{\mathrm{a}, \mathrm{b}}$

\begin{tabular}{|c|c|c|c|c|c|}
\hline \multirow[t]{2}{*}{ Treatment } & \multicolumn{2}{|c|}{ Control diet ${ }^{c}$} & \multicolumn{2}{|c|}{ Enzyme diet ${ }^{d}$} & \multirow{2}{*}{$\begin{array}{l}\text { Contrast } \\
\text { P-value }\end{array}$} \\
\hline & Estimate & SEM & Estimate & SEM & \\
\hline Glucose, $\mathrm{mmol} / \mathrm{L}$ & 7.70 & 0.46 & 7.41 & 0.25 & 0.585 \\
\hline Insulin, pmol/L & 88.92 & 10.99 & 83.35 & 6.06 & 0.664 \\
\hline Insulin:Glucose & 11.56 & 1.21 & 11.08 & 0.67 & 0.734 \\
\hline \multicolumn{6}{|c|}{ Acute phase protein, $\mathrm{mg} / \mathrm{mL}$} \\
\hline Haptoglobin & 1.57 & 0.22 & 1.02 & 0.14 & 0.050 \\
\hline $\mathrm{MBL}^{\mathrm{e}}$ & 125.4 & 8.6 & 117.5 & 5.2 & 0.445 \\
\hline \multicolumn{6}{|l|}{ Cytokine, pg/mL ${ }^{\mathrm{f}}$} \\
\hline GM-CSF & 17.01 & 13.01 & 14.56 & 7.85 & 0.874 \\
\hline IL-1a & 35.01 & 6.81 & 7.50 & 4.27 & 0.004 \\
\hline$I L-1 \beta$ & 1064 & 598 & 1138 & 361 & 0.917 \\
\hline IL-1ra & 428.6 & 257.5 & 673.7 & 161.5 & 0.435 \\
\hline $\mathrm{IL}-2$ & 328.4 & 157.6 & 228.8 & 95.0 & 0.596 \\
\hline IL-4 & 995.5 & 545.6 & 711.6 & 329.0 & 0.662 \\
\hline IL-6 & 190.2 & 61.5 & 98.72 & 38.59 & 0.230 \\
\hline IL-8 & 263.1 & 95.4 & 402.2 & 57.5 & 0.230 \\
\hline IL-10 & 499.4 & 159.1 & 332.9 & 95.9 & 0.383 \\
\hline IL-12 & 1570 & 173 & 1730 & 104 & 0.439 \\
\hline IL-18 & 1994 & 546 & 1380 & 329 & 0.350 \\
\hline TNFa & 24.29 & 39.90 & 52.30 & 25.02 & 0.563 \\
\hline
\end{tabular}

Blood was collected on $\mathrm{d} 8$ of the experiment $6 \mathrm{~h}$ post-feeding, prior to the immune challenge beginning on $\mathrm{d} 10$

${ }^{\mathrm{b}} n=10$ pigs per treatment

${ }^{c}$ Control diet was a corn, soybean mean, and soy hulls based diet containing

$1.33 \% \beta$-mannans, and did not contain $\beta$-mannanase enzyme. Pigs on the control (CON) treatment were fed the control diet and estimates are representative of the CON treatment only

${ }^{d}$ Enzyme diet was the control diet supplemented with $0.056 \% \beta$-mannanase (Hemicell $^{\text {TM }}$ HT-D, Elanco Animal Health, Guelph, ON, Canada; endo-1,4- $\beta$ mannanase $\left(160 \times 10^{6}\right.$ units $\left./ \mathrm{kg}\right)$ from Paenibacillus alvei). Pigs on the enzyme (ENZ) and immune system stimulation (ISS) treatments were fed the enzyme diet. Estimates are representative of the ENZ and ISS treatments prior to immune stimulation

'Mannose binding lectin A (MBL)

${ }^{f}$ Granulocyte-macrophage colony-stimulating factor (GM-CSF); interleukin-1a (IL-1a); interleukin-1 $\beta$ (IL-1 $\beta$ ); interleukin-1 receptor antagonist (IL-1 ra); interleukin-2 (IL-2); interleukin-4 (IL-4); interleukin-6 (IL-6); interleukin-8 (IL-8); interleukin-10 (IL-10); interleukin-12 (IL-12); interleukin-18 (IL-18); tumor necrosis factor alpha (TNFa)

\section{Discussion}

During an immune challenge, pro-inflammatory cytokines initiate a shift in nutrient partitioning away from tissue growth to support activation and maintenance of an immune response $[1,11,31]$. The results of this experiment clearly demonstrated that a systemic inflammatory response to LPS occurred, verified by increased concentrations of pro-inflammatory cytokines and elevated body temperature. To our knowledge, these data are the first to directly relate decreased ADG to increased $\mathrm{ME}_{\mathrm{m}}$ independent of changes in feed intake during an immune response. Additionally, this experiment provides novel data on $\beta$-mannanase supplementation 
Table 5 Growth performance and nitrogen balance in pigs on control, enzyme, or immune system stimulation treatment ${ }^{c}$

\begin{tabular}{|c|c|c|c|c|c|}
\hline Item & $\operatorname{CON}^{d}$ & ENZ $^{\mathrm{e}}$ & $\mathrm{ISS}^{f}$ & SEM & $\begin{array}{l}\text { Treatment } \\
P \text {-value }\end{array}$ \\
\hline \multicolumn{6}{|l|}{ Body Weight, kg } \\
\hline d 0 & 10.23 & 10.21 & 10.38 & 0.15 & 0.651 \\
\hline d 16 & 15.25 & 15.26 & 14.86 & 0.27 & 0.471 \\
\hline ADG d 1-16, g/d & 313.9 & 316.0 & 279.7 & 13.6 & 0.128 \\
\hline \multicolumn{6}{|l|}{ Nitrogen $(\mathrm{N})$ balance, $\mathrm{g} / \mathrm{d}$} \\
\hline Intake & $21.02^{\mathrm{a}}$ & $20.93^{\mathrm{a}}$ & $17.38^{b}$ & 0.95 & 0.021 \\
\hline Excreted & 6.21 & 7.08 & 6.24 & 0.45 & 0.318 \\
\hline In feces & $2.62^{\mathrm{a}}$ & $2.83^{\mathrm{a}}$ & $2.27^{\mathrm{b}}$ & 0.11 & 0.007 \\
\hline In urine & 3.59 & 4.25 & 3.97 & 0.47 & 0.624 \\
\hline Retained & $14.81^{\mathrm{a}}$ & $13.85^{\mathrm{ab}}$ & $11.14^{b}$ & 0.99 & 0.045 \\
\hline$\%$ of excreted $\mathrm{N}$ in feces & 41.31 & 41.21 & 38.42 & 3.29 & 0.778 \\
\hline$\%$ of excreted $\mathrm{N}$ in urine & 58.69 & 58.79 & 61.58 & 3.29 & 0.778 \\
\hline \multicolumn{6}{|c|}{ Nitrogen balance, $\%$ of intake } \\
\hline Excreted in feces & 12.41 & 13.54 & 13.23 & 0.44 & 0.212 \\
\hline Excreted in urine & 17.38 & 21.40 & 24.56 & 4.14 & 0.495 \\
\hline
\end{tabular}

a,b Within a row, treatment means without a common superscript differ, $P<0.05$ $c_{n=10}$ pigs per treatment

${ }^{d}$ Control treatment $(\mathrm{CON})=$ pigs fed basal diet $(0.0 \% \beta$-mannanase $)$ with saline injection

${ }^{e}$ Enzyme treatment $(E N Z)=$ pigs fed enzyme diet $(0.056 \% \beta$-mannanase $)$ with saline injection

${ }^{f}$ Immune system stimulation treatment (ISS) $=$ pigs fed enzyme diet $(0.056 \%$

$\beta$-mannanase) with LPS (Escherichia coli serotype O55:B5) injection

Table 6 Apparent total tract digestibility in pigs on the control, enzyme, or immune system stimulation treatment ${ }^{a}$

\begin{tabular}{|c|c|c|c|c|c|}
\hline Item & $\operatorname{CON}^{b}$ & $\mathrm{ENZ}^{\mathrm{C}}$ & $\mathrm{ISS}^{\mathrm{d}}$ & SEM & $\begin{array}{l}\text { Treatment } \\
P \text {-value }\end{array}$ \\
\hline \multicolumn{6}{|l|}{ ATTD $^{e}, \%$} \\
\hline DM & 88.05 & 87.36 & 87.66 & 0.33 & 0.356 \\
\hline GE & 87.35 & 86.73 & 86.86 & 0.33 & 0.418 \\
\hline$C P$ & 87.59 & 86.47 & 86.77 & 0.44 & 0.212 \\
\hline $\mathrm{EE}^{\mathrm{f}}$ & 70.41 & 69.62 & 66.85 & 1.18 & 0.122 \\
\hline Starch & 99.41 & 99.50 & 99.56 & 0.10 & 0.565 \\
\hline NDF & 68.81 & 66.11 & 70.23 & 1.55 & 0.178 \\
\hline ADF & 71.65 & 68.04 & 74.13 & 2.26 & 0.175 \\
\hline Hemicellulose ${ }^{g}$ & 65.00 & 63.51 & 64.99 & 0.92 & 0.429 \\
\hline
\end{tabular}

${ }^{a} n=10$ pigs per treatment

${ }^{b}$ Control treatment $(\mathrm{CON})=$ pigs fed basal diet $(0.0 \% \beta$-mannanase $)$ with saline injection

${ }^{C}$ Enzyme treatment $(E N Z)=$ pigs fed enzyme diet $(0.056 \% \beta$-mannanase $)$ with saline injection

${ }^{d}$ Immune system stimulation treatment (ISS) $=$ pigs fed enzyme diet $(0.056 \%$ ß-mannanase) with LPS (Escherichia coli serotype O55:B5) injection

${ }^{\mathrm{e}}$ ATTD, $\%=[($ nutrient intake $(\mathrm{kg})-$ fecal nutrient output $(\mathrm{kg})) /$ nutrient intake $(\mathrm{kg})] \times 100$

${ }^{\mathrm{f}}$ Acid hydrolyzed ether extract

${ }^{9}$ Hemicellulose $=$ NDF - ADF
Table 7 Effect of treatment on energy balance, respiratory quotient, maintenance energy requirements, and nutrient deposition ${ }^{c}$

\begin{tabular}{|c|c|c|c|c|c|}
\hline \multirow[b]{2}{*}{ Item } & \multicolumn{4}{|c|}{ Treatment } & \multirow{2}{*}{$\begin{array}{l}\text { Treatment } \\
P \text {-value }\end{array}$} \\
\hline & $\mathrm{CON}^{d}$ & $\mathrm{ENZ}^{\mathrm{e}}$ & $1 S S^{f}$ & SEM & \\
\hline Day 16 BW, kg & 14.37 & 14.19 & 13.77 & 0.26 & 0.313 \\
\hline Day 16 DMl, kg & 0.51 & 0.51 & 0.46 & 0.03 & 0.348 \\
\hline
\end{tabular}

Energy balance, $\mathrm{kcal} / \mathrm{kg} \mathrm{BW} \mathrm{W}^{0.60} / \mathrm{kg} \mathrm{DMI} / \mathrm{d}$

$\begin{array}{lccccc}\text { ME intake } & 771.3 & 755.9 & 751.1 & 37.7 & 0.924 \\ \text { Heat production }^{9} & & & & & \\ \text { HP }_{\text {total }} & 278.8^{\mathrm{b}} & 274.9^{\mathrm{b}} & 333.0^{\mathrm{a}} & 14.9 & 0.040 \\ \mathrm{FHP}_{\text {total }} & 287.8 & 276.0 & 324.3 & 17.1 & 0.178 \\ \text { FHP } & 207.8 & 206.6 & 243.3 & 12.9 & 0.135\end{array}$

Retained energy ${ }^{\text {h }}$

$\begin{array}{cccccc}\text { As protein } & 197.5 & 173.6 & 191.0 & 18.3 & 0.627 \\ \text { As lipid } & 291.4^{\mathrm{a}} & 302.9^{\mathrm{a}} & 227.7^{\mathrm{b}} & 19.2 & 0.046 \\ \text { Total } & 488.9 & 476.5 & 418.7 & 32.0 & 0.318 \\ \mathrm{k}_{\mathrm{mg}} \text { \% } & 87.07 & 86.44 & 83.01 & 1.34 & 0.130 \\ {\text { Estimated } M E_{\mathrm{m}}} & 239.0^{\mathrm{b}} & 239.5^{\mathrm{b}} & 295.5^{\mathrm{a}} & 15.3 & 0.045\end{array}$

Retained energy, \% of ME intake

$\begin{array}{llllll}\text { As protein } & 25.68 & 23.15 & 24.99 & 1.27 & 0.354 \\ \text { As lipid } & 37.77^{\mathrm{a}} & 40.07^{\mathrm{a}} & 29.81^{\mathrm{b}} & 2.02 & 0.013 \\ \text { Total } & 63.44^{\mathrm{a}} & 63.22^{\mathrm{a}} & 54.80^{\mathrm{b}} & 2.18 & 0.033\end{array}$

Respiratory quotient

$\begin{array}{llllll}\text { Fed state } & 0.92 & 0.90 & 0.88 & 0.01 & 0.225 \\ \text { Fasting state } & 0.74 & 0.73 & 0.73 & 0.01 & 0.381\end{array}$

Nutrient deposition', g/d

$\begin{array}{cccccc}\text { As protein } & 87.74 & 78.55 & 69.80 & 5.86 & 0.150 \\ \text { As lipid } & 76.22^{\mathrm{a}} & 79.43^{\mathrm{a}} & 55.45^{\mathrm{b}} & 6.21 & 0.047 \\ \text { ADG d 10-16, g/d } & 447.1^{\mathrm{a}} & 404.8^{\mathrm{a}} & 330.7^{\mathrm{b}} & 21.3 & 0.010\end{array}$

a,b Within a row, treatment means without a common superscript differ, $P<0.05$ ${ }^{c} n=7$ pigs per treatment (CON and ENZ) and 6 pigs per treatment (ISS) ${ }^{d}$ Control treatment $(\mathrm{CON})=$ pigs fed basal diet $(0.0 \% \beta$-mannanase $)$ with saline injection

eEnzyme treatment $(E N Z)=$ pigs fed enzyme diet $(0.056 \% \beta$-mannanase $)$ with saline injection

Immune system stimulation treatment (ISS) = pigs fed enzyme diet $(0.056 \%$ $\beta$-mannanase) with LPS (Escherichia coli serotype O55:B5) injection ${ }^{9}$ Heat production $(\mathrm{HP})=\left(3.87 \times \mathrm{O}_{2}\right.$ consumption $(\mathrm{L})+1.20 \times \mathrm{CO}_{2}$ production $(\mathrm{L})$ $-1.43 \times$ urinary N)/BW ${ }^{0.60}(\mathrm{~kg})$ [22]; Total HP $\left(\mathrm{HP}_{\text {total }}\right)=$ avg. $\mathrm{HP}$ over $22 \mathrm{~h}$ fed state, post- challenge; Total fasting HP $\left(\mathrm{FHP}_{\text {total }}\right)=$ avg. HP over $12 \mathrm{~h}$ fasted state; Fasting HP $(\mathrm{FHP})=$ avg. of 10 lowest HP values over the $12 \mathrm{~h}$ fasted state $[27,28] ; \mathrm{HP}_{10}=$ avg. $\mathrm{HP}$ over $10 \mathrm{~h}$ post-challenge $(10: 00 \mathrm{~h}-20: 00 \mathrm{~h})$, fed state; $\mathrm{HP}_{\text {low }}=$ avg. of 10 lowest $\mathrm{HP}$ values over $10 \mathrm{~h}$ post-challenge $(10: 00 \mathrm{~h}-$

20:00 h), fed state; Activity HP (AHP) $=\mathrm{HP}_{10}-\mathrm{HP}_{\text {lowi }}$ Thermic effect of feeding $(T E F)=H P_{10}-A H P-F H P ;$ Heat increment $(H I)=A H P+T E F ;$ ME efficiency for maintenance and growth $\left(\mathrm{k}_{\mathrm{mg}}\right)=(1-\mathrm{HI}) \times 100$ [25]; ME used for maintenance $\left(\mathrm{ME}_{\mathrm{m}}\right)=\mathrm{FHP} \times 100 / \mathrm{k}_{\mathrm{mg}}[25]$

${ }^{\mathrm{h}}$ Retained energy $(\mathrm{RE})=\mathrm{ME}$ intake - total fed-state HP, pre-and post-challenge [29]; $\mathrm{RE}$ as protein $\left(\mathrm{RE}_{\mathrm{p}}\right)=[\mathrm{PD}(\mathrm{g}) \times 5.66(\mathrm{kcal} / \mathrm{g})] / \mathrm{BW}^{0.60} / \mathrm{DMI}[30]$; $\mathrm{RE}$ as lipid $\left(R E_{1}\right)=R E-R E_{p}[30]$

'Protein deposition $=$ nitrogen retention $(\mathrm{g}) \times 6.25$; Lipid deposition $=\mathrm{RE}_{\mathrm{f}}(\mathrm{kcal})$ / 9.49 (kcal/g) [30] 
Table 8 Dietary energy values and efficiency in pigs on control, enzyme, or immune system stimulation treatment ${ }^{a}$

\begin{tabular}{|c|c|c|c|c|c|}
\hline \multirow[b]{2}{*}{ Item } & \multicolumn{4}{|c|}{ Treatment } & \multirow{2}{*}{$\begin{array}{l}\text { Treatment } \\
P \text {-value }\end{array}$} \\
\hline & $\overline{\mathrm{CON}^{\mathrm{b}}}$ & $\overline{E N Z^{C}}$ & $1 S S^{d}$ & $\overline{\text { SEM }}$ & \\
\hline
\end{tabular}

Dietary energy value ${ }^{e}, \mathrm{Mcal} / \mathrm{kg} \mathrm{DM}$

$\begin{array}{clllll}\text { GE } & 4.65 & 4.59 & 4.59 & & \\ \mathrm{DE} & 4.07 & 3.99 & 4.00 & 0.02 & 0.051 \\ \mathrm{ME} & 3.96 & 3.86 & 3.89 & 0.03 & 0.052 \\ \mathrm{NE} & 3.29 & 3.30 & 3.11 & 0.19 & 0.748 \\ \text { ME/DE efficiency, \% } & 97.31 & 96.92 & 97.35 & 0.37 & 0.457 \\ \text { NE/ME efficiency, \% } & 83.09 & 85.31 & 80.03 & 4.42 & 0.701\end{array}$

${ }^{a} n=7$ pigs per treatment (CON and ENZ) and 6 pigs per treatment (ISS)

${ }^{\mathrm{b}}$ Control treatment $(\mathrm{CON})=$ pigs fed basal diet $(0.0 \% \beta$-mannanase) with saline injection

${ }^{c}$ Enzyme treatment $(E N Z)=$ pigs fed enzyme diet $(0.056 \% \beta$-mannanase $)$ with saline injection

${ }^{d}$ Immune system stimulation treatment (ISS) $=$ pigs fed enzyme diet $(0.056 \%$ $\beta$-mannanase) with LPS (Escherichia coli serotype O55:B5) injection

${ }^{e}$ Gross energy (GE) analyzed via bomb calorimetry; digestible energy (DE) $=\mathrm{GE}$ apparent total tract digestibility coefficient $\times$ diet $\mathrm{GE}$; metabolizable energy $(\mathrm{ME})=\mathrm{DE}-$ (urinary energy $+0.4 \%$ of $\mathrm{DE}$ intake); net energy $(\mathrm{NE})=$ (retained energy + fasting heat production)/DMI

effects on immune parameters and energy balance in pigs.

\section{$\beta$-mannanase}

As a constituent of hemicellulose, $\beta$-mannan is not digested by mammalian endogenous enzymes [32]. Thus, intact $\beta$-mannans are available to bind carbohydrate recognition domains of pattern recognition receptors on innate immune cells surveying the intestinal epithelium for potential pathogens $[3,33]$. In this way, $\beta$-mannans are hypothesized to be capable of stimulating innate immune cells resulting in a nonproductive, energy draining immune response [4-6].

Commonly, only growth and feed efficiency responses have been measured from $\beta$-mannanase and reported in the animal nutrition literature. Reduced feed efficiency and ADG have been reported with increasing dietary $\beta$-mannan concentrations [34]. Therefore, there is interest in $\beta$-mannanase supplementation to alleviate these negative effects by enzymatic hydrolysis of $\beta$-mannan polysaccharides. The FIIR was alleviated through $\beta$-mannanase supplementation in poultry $[6,35]$; however, $\beta$-mannanase supplementation responses in swine have been inconsistent. This experiment demonstrated no $\beta$-mannanase effect on the ATTD of DM, GE, CP, EE, or hemicellulose. Growth performance responses are similarly inconsistent with positive results in some studies [36-38] but no $\beta$-mannanase effect in others [39-42]. In this experiment, ENZ did not improve ADG, protein, or lipid deposition.

Dietary $\beta$-mannans are proposed to stimulate the innate immune system through direct interactions with the carbohydrate binding domains of mannose recognition receptors such as the membrane bound mannose receptor and secreted MBL. Therefore, serum MBL concentrations were measured to determine if $\beta$-mannanase supplementation decreased circulating MBL, theoretically by removing the substrate for activation and synthesis. Serum MBL concentrations were not affected by $\beta$-mannanase. This may indicate that the $\beta$-mannan concentration in the intestinal lumen was not high enough to either interact with MBL, MBL-dietary $\beta$-mannan interaction was not affected by $\beta$-mannanase supplementation, or this interaction is not a mechanism through which $\beta$-mannans are sensed by the innate immune system.

Two significant differences in serum parameters were detected when contrasts were applied to compare pre-challenge values between control pigs (no $\beta$-mannanase, CON treatment) and $\beta$-mannanase supplemented pigs (ENZ and ISS treatments). Beta-mannanase supplementation decreased serum haptoglobin and IL- $1 \alpha$ concentrations. In poultry, decreased haptoglobin has been proposed as evidence of immune stress alleviation due to $\beta$-mannanase supplementation [6]. However, this response occurred in conjunction with growth performance and feed efficiency improvements which were not observed in this study. Beta-mannanase effects on IL- $1 \alpha$ concentrations have not been previously reported. Interleukin-1-alpha can be involved in inflammation initiation, but the relationship between serum concentration and magnitude of immune challenge is not as clear as the implication of its counterpart, IL- $1 \beta$ on systemic inflammation [43]. Interleukin-1-beta concentrations were not affected by $\beta$-mannanase supplementation in this study.

In total, decreased serum IL-1 $\alpha$ and haptoglobin concentrations are not strong enough evidence of an alleviated systemic FIIR when taken in context with the lack of all other measured inflammatory-type variables. Importantly, no differences were observed in $\mathrm{HP}, \mathrm{ME}_{\mathrm{m}}$, and growth performance. It is possible that a localized response may have occurred at the intestinal level yet went undetected systemically. However, if this occurred, whole body nutrient and energy partitioning were still unaffected. The hypothesis that $\beta$-mannanase supplementation would decrease $\mathrm{ME}_{\mathrm{m}}$ was not supported. Pigs fed diets supplemented with $\beta$-mannanase had similar WBC counts, cytokine concentrations, nutrient digestibility, ADG, $\mathrm{N}$ and energy balance, $\mathrm{PD}, \mathrm{LD}$, and $\mathrm{ME}_{\mathrm{m}}$ compared to $\mathrm{CON}$ pigs.

\section{Immune stimulation}

Innate immune stimulation was successfully induced in pigs using sequential, increasing doses of E. coli LPS. Elevated rectal temperature, increased pro-inflammatory cytokine concentrations, and altered nutrient and energy partitioning are all hallmarks of a chronic immune challenge [1] and were observed in ISS pigs in this study. 
One limitation of this study was the number of calorimetry chambers available which limited the experiment to a total of three treatments. Due to this limitation, we were unable to evaluate the interaction of $\beta$-mannanase supplementation with LPS immune stimulation. Thus, interpretation of ISS effects has been made in comparison to the ENZ treatment. However, as discussed above, there were no differences between the CON and ENZ treatments in nutrient digestibility, ADG, or $\mathrm{N}$ and energy balance. The major finding of this research indicates that the innate immune challenge increased young pig maintenance energy requirements by $23.3 \%$ which translated into a $18.3 \%$ decrease in ADG.

Unique to this study, decreased ADG could be attributed primarily toward increased $\mathrm{ME}_{\mathrm{m}}$ in ISS pigs as opposed to decreased feed intake or effects on nutrient digestibility. Anorexia is a well-established response to systemic immune stimulation $[2,9,44]$ induced by pro-inflammatory cytokine actions (especially IL-1 $\beta$ ) in the brain and modulation of metabolism and hormone release [45]. In this study, a numerical but not statistically significant decrease in ADFI was observed in ISS pigs during the challenge period even though IL- $1 \beta$ increased. It is likely that a stronger ADFI decrease was not observed as a consequence of challenging the pigs $2 \mathrm{~h}$ post-feeding and limit feeding to 2.5 times maintenance energy requirements [12]. This feeding level was designed to achieve similar ADFI for pigs on all treatments because of the known effect of previous feeding level on HP [25]. To further ensure HP results were separated from feed intake and BW effects, all energy balance calculations were conducted on a $\mathrm{kcal} / \mathrm{BW}^{0.60} /$ $\mathrm{DMI} / \mathrm{d}$ basis. Just as feed intake did not influence the observed decrease in ADG of ISS pigs, nutrient digestibility was not different across treatments. This is in agreement with other studies reporting ATTD during a chronic LPS challenge [46, 47].

\section{Febrile response}

Before the challenge period, rectal temperatures and blood immune parameters in ISS pigs were not different from those on the CON and ENZ treatments. This confirmed that prior to the challenge all pigs were in good health and of similar immune status. Therefore, any subsequent differences during the challenge were attributed to LPS immune stimulation. Elevated rectal temperatures $\left(>40{ }^{\circ} \mathrm{C}\right)$ post-challenge on $\mathrm{d} 10,12$, and 14 indicated a febrile response in ISS pigs.

Fever is energetically expensive with increased caloric requirement estimates ranging from 7 to $15 \%$ for each $1{ }^{\circ} \mathrm{C}$ increase in body temperature [48]. Utilizing the average rectal temperature of CON and ENZ pigs and the post-challenge temperature of ISS pigs on day 14, an increase of $1.2{ }^{\circ} \mathrm{C}$ resulted in a $23.6 \%$ increase in $\mathrm{ME}_{\mathrm{m}}$ caloric requirements. This value is higher than the previously described range and may indicate that the majority, but not all of the increase in maintenance caloric requirement is to support the febrile response. The remainder may be partially explained by an increase in immune cell glucose requirements [11].

\section{Cytokines}

Key pro-inflammatory cytokines include TNFo, IL-6, and IL-1 $\beta$ [49] and ISS pigs had increased serum concentrations of all three after the first LPS challenge. Pro-inflammatory cytokines shift metabolism away from anabolic processes toward a more catabolic state to generate AAs and energy necessary to support fever, increase immune cell proliferation, and APP synthesis [50, 51]. In this study, the pro-inflammatory cytokine profile of ISS pigs clearly shifted metabolism toward a lipolytic state and this resulted in significantly less energy retained as lipid and decreased lipid deposition compared to non-immunologically challenged pigs.

\section{Complete blood count}

Immune stimulation decreased WBC counts, specifically neutrophils, lymphocytes, and monocytes. This is similar to other instances of leukopenia observed due to LPS administration [11, 52]. However, WBC distribution drastically changed following LPS administration and circulating concentrations are dependent upon the time of sampling relative to immune challenge $[52,53]$. Thus, variable responses in WBC counts have been reported due to LPS immune stimulation. Rakhshandeh and de Lang observed 1.6 times greater WBC [8] in one study, but in a second, WBC count decreased by $9 \%$ [54]. At the time of sampling in this study, leukocyte extravasation into the LPS injection site and into immunologically important tissues likely explains the observed leukopenia.

\section{Acute phase proteins}

In addition to increased pro-inflammatory cytokine production and leukocyte migration that occur during infection, the acute phase response typically includes increased APP synthesis by the liver. However, in this study, ISS APP concentrations did not differ compared to CON. This was an unexpected result because LPS has been demonstrated to increase APPs such as haptoglobin $[8,46]$ and C-reactive protein [55] in pigs. A less responsive APP, MBL has been demonstrated to attenuate LPS-induced pro-inflammatory cytokine production [56] and inhibit T-lymphocyte activation [57]. However, in this study it did not appear that LPS induced greater MBL or haptoglobin production.

Although a MBL response was not necessarily expected, a haptoglobin response was. Haptoglobin is a primary APP in pigs and is synthesized in the liver when 
activated by IL-6 and to a lesser extent IL-1 [58], both of which were significantly elevated in ISS pigs post-challenge. Similar to our results, Koopmans et al. [55] discussed unpublished data which showed no LPS effect on haptoglobin concentrations even though there were clear increases in plasma cortisol, TNF $\alpha$, IL-6, and C-reactive protein over a 24-h period after LPS challenge. One possible explanation for a lack of haptoglobin response could be time related. Serum samples in this study were collected $4 \mathrm{~h}$ after the first challenge and haptoglobin may be a better indicator of chronic inflammation [59].

\section{Nitrogen balance}

Disease is associated with decreased growth performance and changes in nutrient partitioning. Often, $\mathrm{N}$ metabolism is affected because of increasing AA requirements for immune cell proliferation and APP synthesis [51]. In this study, only numerical decreases in protein deposition were measured in ISS pigs compared to CON and ENZ. If protein catabolism had increased to provide AAs for APPs, an increase in urinary $\mathrm{N}$ would have been expected because APPs have a distinctly different AA profile than skeletal muscle $[50,60]$. However, due to the high dietary $\mathrm{CP}$ concentration, it is possible that these excessive dietary amino acids may have provided the additional amino acids required for APP synthesis and prevented the typically observed increase in skeletal muscle protein catabolism.

\section{Energy balance}

Disease is well known to be detrimental to pig efficiency and productivity. A considerable amount of research has focused on products to mitigate the drop in performance $[13,61]$ or prevent initial disease onset [62]. Yet few studies have evaluated the energetic cost of an immune challenge in order to generate more effective dietary interventions. In this study, total HP increased by $21.1 \%$ in ISS pigs compared to the ENZ treatment.

Campos et al. [46] also evaluated HP components during an immune response and reported significant decreases in ADFI leading to decreased TEF compared to baseline values. In this study DMI did not differ, potential feed intake effects on TEF were removed by interpreting the data after normalizing to a constant feed intake, and TEF values were not affected by ISS. Therefore, both experiments indicate that a chronic inflammatory response did not increase HP through increased TEF. This is supported by the lack of treatment differences in diet digestibility and further supports our supposition that the impact of immune stimulation on energy balance in this study is not through influences on diet digestion or nutrient uptake.
However, it is clear that energy partitioning between maintenance and growth was affected by ISS. A $23.3 \%$ increase in $\mathrm{ME}_{\mathrm{m}}$ was detected due to ISS. As caloric requirements for maintenance increased to support the immune system, less dietary energy was retained for growth. This manifested as less $\mathrm{RE}_{1}$ resulting in a $30.2 \%$ decrease in lipid deposition.

Previous studies across all species have related increased caloric requirements with fever $[48,63]$, but few have directly related a chronic immune challenge with increased $\mathrm{ME}_{\mathrm{m}}$. In vitro studies with isolated mitochondria from rats stimulated with TNF $\alpha$ or IL-1 showed up to $30 \%$ increases in respiration rate [64]. Demas et al. [63] reported that mice injected with a mild antigen had limited immune activation that resulted in significantly more $\mathrm{O}_{2}$ consumption than control mice injected with saline. Interleukin-six infusions in humans increased resting metabolic rates by $25 \%$ [65].

In pigs, the direct relationship between immune stimulation and increased energy requirements has not previously been demonstrated. Some studies reported that immune system stimulation did not impact growth, efficiency, or energy balance measurements [66, 67] However, Moon et al. [66] reported fibroblast formation at the injection site which encapsulated the immunogen and prevented systemic delivery. Williams et al. [67] used the comparative slaughter technique and reported no differences in the energetic costs of maintenance, PD, and LD between pigs raised in environments encouraging high or low chronic immune activation.

Conversely, Labussière et al. [68] and Campos et al. [46] reported decreased HP in pigs during inflammatory challenges. Labussière et al. [68] administered a single injection of complete Freund's adjuvant to young weaned pigs but did not measured HP until the day after challenge and only re-entered the calorimetry chamber after visual recovery [68]; and this likely biased the response. Campos et al. [46] reported a 14\% decrease in total HP $\left(\mathrm{kcal} / \mathrm{BW}^{0.60} / \mathrm{d}\right)$ in response to a repeated LPS challenge in growing pigs even though typical inflammatory-type and febrile responses were observed. Decreased HP was mainly attributed to lower TEF which reflected the effect of feed intake depression on HP. According to the relationship reported by Labussière et al. [25], lower ADFI should have decreased $\mathrm{ME}_{\mathrm{m}}$ by $24 \mathrm{kcal} / \mathrm{BW}^{0.60} / \mathrm{d}$. Because this drop in $\mathrm{ME}_{\mathrm{m}}$ did not occur, the authors reasoned that the immune stimulation did in fact increase $\mathrm{ME}_{\mathrm{m}}$ relative to baseline [46]. This supports our experimental model of limit feeding to encourage similar feed intake and to evaluate energy balance on a $\mathrm{kcal} / \mathrm{BW}^{0.60} / \mathrm{DMI} / \mathrm{d}$ basis. Feed intake clearly influences and can bias HP results and interpretations.

Interpretation of our results in context with the previously discussed reports suggests that an inflammatory 
response does increase $\mathrm{ME}_{\mathrm{m}}$ relative to healthy control animals, but in some experiments this response may be masked by decreased HP related to decreased feed intake. This may mean that during an immune response the total caloric requirement may not drastically change because of decreased feed intake, but how those calories are partitioned does change; and this results in growth and feed efficiency depressions commonly observed during disease challenges.

These results supported our hypothesis that energy partitioning shifts to allocate more energy for initiation and maintenance of immune functions and less toward nutrient deposition. Other research would support changes in $\mathrm{N}$ metabolism $[46,67,69]$ whereas our data suggest that less energy was allocated for LD. Both result in decreased ADG and efficiency losses in pork production, yet these effects are generally given little consideration in commercial swine feeding practices.

\section{Conclusions}

This experiment provides novel data on $\beta$-mannanase supplementation effects on immune parameters and energy balance in pigs. Beta-mannanase supplementation did not benefit immune status, nutrient digestibility, growth performance, energy balance, or $\mathrm{ME}_{\mathrm{m}}$ in young pigs fed a corn, soybean meal, and soybean hulls-based diet. More research is needed to determine how $\beta$-mannanase functions in pigs and in which environments and diets it might be effective. These novel data directly relate decreased ADG to increased $\mathrm{ME}_{\mathrm{m}}$ independent of changes in feed intake in immune challenged pigs. An innate immune challenge increased proinflammatory cytokine concentrations which induced a febrile response and elevated $\mathrm{HP}$ and $\mathrm{ME}_{\mathrm{m}}$ by $23.3 \%$. Increased energy partitioning toward the immune response limited LD by $30.2 \%$ leading to a $18.3 \%$ decrease in ADG during the immune challenge. These data expand upon the available literature to describe the magnitude of increase in $\mathrm{ME}_{\mathrm{m}}$ in immune challenged pigs relative to healthy control animals. Understanding the extent to which energy requirements and nutrient deposition change in pigs experiencing sustained immune stress may help develop more effective feeding strategies for health challenged herds and encourage appreciation for the economic benefits of maintaining high health populations.

\section{Additional files}

Additional file 1: Table S1. Pre-test diet ingredient and analyzed nutrient composition. Table provides ingredient and nutrient composition of the common, pre-test diet all pigs were fed prior to initiating experiment. (DOCX $17 \mathrm{~kb}$ )

Additional file 2: Table S2. Effect of treatment on pre- and post-challenge complete blood count values. Table provides LS means, time by treatment
$P$-values, time $P$-values, and treatment $P$-values, as well as means comparisons results for complete blood count response variables. (DOCX $20 \mathrm{~kb}$ )

Additional file 3: Table S3. Effect of treatment on serum glucose, insulin, acute phase protein, and cytokine concentrations. Table provides LS means, time by treatment $P$-values, time $P$-values, and treatment $P$ values, as well as means comparisons results for serum glucose, insulin, acute phase protein, and cytokine response variables. (DOCX 26 kb)

\section{Abbreviations}

IL-1a: Interleukin-1-alpha; TNFa: Tumor necrosis factor-alpha; AA: Amino acid; ADF: Acid detergent fiber; ADFl: Average daily feed intake; ADG: Average daily gain; AHP: Activity heat production; APP: Acute phase protein; ATTD: Apparent total tract digestibility; BW: Body weight; CBC: Complete blood count; CON: Control treatment; CP: Crude protein; DE: Digestible energy; DM: Dry matter; DMI: Dry matter intake; EE: Acid hydrolyzed ether extract; ENZ: Enzyme treatment; FHP: Fasting heat production; FHP total: Total fasting heat production; FIIR: Feed-induced immune response; GE: Gross energy; GM-CSF: Granulocyte macrophage colony-stimulating factor; HI: Heat increment; $\mathrm{HP}$ : Heat production; $\mathrm{HP}_{10}$ : Heat production over $10 \mathrm{~h}$ postchallenge; $\mathrm{HP}_{\text {low: }}$ : Average of 10 lowest HP values over $10 \mathrm{~h}$ post-challenge; $\mathrm{HP}_{\text {total: }}$ Total heat production; IL: Interleukin; IL-1 ra: Interleukin-1-receptor antagonist; ISS: Immune system stimulation treatment; $\mathrm{k}_{\mathrm{mg}}$ : Energy efficiency for maintenance and growth; LD: Lipid deposition; LPS: Lipopolysaccharide; MBL: Mannose binding lectin; ME: Metabolizable energy; $\mathrm{ME}_{\mathrm{m}}$ : Metabolizable energy used for maintenance; N: Nitrogen; NDF: Neutral detergent fiber; NE: Net energy; NR: Nitrogen retention; PD: Protein deposition; RE: Retained energy; RE.: Retained energy as lipid; $\mathrm{RE}_{\mathrm{p}}$ : Retained energy as protein; RFI: Residual feed intake; RQ: Respiratory quotient; $\mathrm{RQ}_{\text {fast: }}$ Respiratory quotient during the fasting period of heat production measurements;

$\mathrm{RQ}_{\mathrm{fed}}$ : Respiratory quotient during the fed period of heat production measurements; TEF: Thermic effect of feeding; $\mathrm{VCO}_{2}$ : Volume of carbon dioxide produced; $\mathrm{VO}_{2}$ : Volume of oxygen consumed; WBC: White blood cell

\section{Acknowledgments}

The authors would like to thank Deepak Velayundhan and Atta Agyekum for their technical assistance, Elanco ${ }^{\oplus}$ for financial support of this research, and National Pork Board for financial support of Nichole Huntley's graduate program.

\section{Funding}

Financial support of $\mathrm{NH}$ graduate program provided by the National Pork Board. Financial and in-kind support provided by Elanco, Greenfield, IN, USA. Neither funding agency had a role in the design, analysis, or writing of this article.

\section{Availability of data and materials}

All data generated or analyzed during this study are included in this published article and its additional information files.

\section{Authors' contributions}

$\mathrm{NH}$ and JP designed the study and had primary responsibility for the final content of the manuscript; CMN provided essential equipment and materials; $\mathrm{NH}$ conducted the research with the assistance of CMN graduate students; and $\mathrm{NH}$ analyzed data and wrote the manuscript. All authors have read and approved the final manuscript.

\section{Ethics approval}

All experimental procedures adhered to guidelines for the ethical and humane use of animals for research and were reviewed and approved by the University of Manitoba Animal Care Committee.

\section{Competing interests}

The authors declare that they have no competing interests.

\section{Author details}

'Department of Animal Science, lowa State University, Ames, IA 50011, USA. ${ }^{2}$ Department of Animal Science, University of Manitoba, 226 Animal Science Building, Winnipeg, MB R3T 2N2, Canada. 


\section{Received: 7 December 2017 Accepted: 14 May 2018}

Published online: 15 June 2018

\section{References}

1. Gabler N, Spurlock M. Integrating the immune system with the regulation of growth and efficiency. J Anim Sci. 2008;86:E64-74.

2. Mani V, Weber TE, Baumgard LH, Gabler NK. Endotoxin, inflammation, and intestinal function in livestock. J Anim Sci. 2012;90:1452-65.

3. Gazi U, Martinez-Pomares L. Influence of the mannose receptor in host immune responses. Immunobiology. 2009;214:554-61.

4. Zhang L, Tizard IR. Activation of a mouse macrophage cell line by acemannan: the major carbohydrate fraction from Aloe vera gel. Immunopharmacology. 1996;35:119-28.

5. Duncan CJG, Pugh N, Pasco DS, Ross SA. Isolation of a galactomannan that enhances macrophage activation from the edible fungus Morchella esculenta. J Agric Food Chem. 2002;50:5683-5.

6. Anderson DM, Hsiao HY, Dale NM. Identification of an inflammatory compound for chicks in soybean meal. Poult Sci. 2008;88:153.

7. Li Y, Chen X, Chen Y, Li Z, Cao Y. Effects of $\beta$-mannanase expressed by Pichia pastoris in corn-soybean meal diets on broiler performance, nutrient digestibility, energy utilization and immunoglobulin levels. Anim Feed Sci Technol. 2010;159:59-67.

8. Rakhshandeh A, de Lange CFM. Evaluation of chronic immune system stimulation models in growing pigs. Animal. 2012;6:305-10.

9. Wright KJ, Balaji R, Hill CM, Dritz SS, Knoppel EL, Minton JE. Integrated adrenal, somatotropic, and immune responses of growing pigs to treatment with lipopolysaccharide. J Anim Sci. 2000;78:1892-9.

10. Baracos VE, Whitmore WT, Gale R. The metabolic cast of fever. Can J Physiol Pharmacol. 1987:65:1248-54.

11. Kvidera SK, Horst EA, Abuajamieh M, Mayorga EJ, Fernandez MVS, Baumgard $\mathrm{LH}$. Estimating glucose requirements of an activated immune system in growing pigs. J Anim Sci. 2017;95:5020-9.

12. NRC. Nutrient requirements of swine. 11th revis. Washington, DC: National Academy Press; 2012.

13. Gabler NK, Spencer JD, Webel DM, Spurlock ME. N-3 PUFA attenuate lipopolysaccharide-induced down-regulation of toll-like receptor 4 expression in porcine adipose tissue but does not alter the expression of other immune modulators. J Nutr Biochem. 2008;19:8-15.

14. Velayudhan DE, Heo JM, Nyachoti CM. Net energy content of dry extrudedexpelled soybean meal fed with or without enzyme supplementation to growing pigs as determined by indirect calorimetry. J Anim Sci. 2015;93: 3402-9.

15. Ayoade DI, Kiarie E, Neto T, Nyachoti CM. Net energy of diets containing wheat-corn distillers dried grains with soluble as determined by indirect calorimetry, comparative slaughter, and chemical composition methods. J Anim Sci. 2012;90:4373-9.

16. Aulick LH, Arnhold H, Hander EH, Mason AD. A new open and closed respiration chamber. Q J Exp Physiol. 1983;68:351-7.

17. AOAC. In: Horwitz W, Latimer GW, editors. Official methods of analysis of AOAC international. 18th ed. Association of Official Analytical Chemists International: Gaithersburg; 2007.

18. Van Soest PJ, Robertson JB. Systems of analysis for evaluating fibrous feeds. In: Pigden WJ, Balch CC, Graham M, editors. Work stand anal Methodol feed. Ottawa: International Development Research Centre; 1979. p. 49-60.

19. Goering HK, Van Soest PJ. Forage fiber analyses (apparatus, reagents, procedures, and some applications). Agric Handb. 1970:379:1-20.

20. Noblet J, van Milgen J. Energy value of pig feeds: effect of pig body weight and energy evaluation system. J Anim Sci. 2004;82:E229-38.

21. Noblet J, Fortune H, Shi XS, Dubois S. Prediction of net energy value of feeds for growing pigs. J Anim Sci. 1994;72:344-54.

22. Brouwer $E$. Report of the sub-committee on constants and factors. In: Blaxter L, editor. Proc 3rd Symp energy Metab. London: Academic Press; 1965. p. 441-3.

23. Jørgensen $\mathrm{H}$. Methane emission by growing pigs and adult sows as influenced by fermentation. Livest Sci. 2007;109:216-9.

24. Noblet J, Karege C, Dubois S, Van Milgen J. Metabolic utilization of energy and maintenance requirements in growing pigs: effects of sex and genotype. J Anim Sci. 1999;77:1208-16.

25. Labussière $E$, van Milgen J, CFM d L, Noblet J. Maintenance energy requirements of growing pigs and calves are influenced by feeding level. $J$ Nutr. 2011;141:1855-61.
26. Noblet J, Shi XS, Dubois S. Effect of body weight on net energy value of feeds for growing pigs. J Anim Sci. 1994;72:648-57.

27. Krueger R, Derno M, Goers S, Metzler-Zebeli BU, Nuernberg G, Martens K, et al. Higher body fatness in intrauterine growth retarded juvenile pigs is associated with lower fat and higher carbohydrate oxidation during ad libitum and restricted feeding. Eur J Nutr. 2014;53:583-97.

28. Derno M, Jentsch W, Schweigel M, Kuhla S, Metges CC, Matthes HD. Measurements of heat production for estimation of maintenance energy requirements of Hereford steers. J Anim Sci. 2005;83:2590-7.

29. Labussière E, Dubois S, van Milgen J, Noblet J. Partitioning of heat production in growing pigs as a tool to improve the determination of efficiency of energy utilization. Front Physiol. 2013:4:1-10.

30. Gerrits WJJ, Bosch MW, van den Borne JJGC. Quantifying resistant starch using novel, in vivo methodology and the energetic utilization of fermented starch in pigs. J Nutr. 2012;142:238-44.

31. Johnson RW. Inhibition of growth by pro-inflammatory cytokines: an integrated view. J Anim Sci. 1997;75:1244-55.

32. Choct M, Dersjant-Li Y, McLeish J, Peisker M. Soy oligosaccharides and soluble non-starch polysaccharides: a review of digestion, nutritive and antinutritive effects in pigs and poultry. Asian-Australasian J Anim Sci. 2010;23: 1386-98.

33. Kraehenbuhl J-P, Corbett M. Keeping the gut microflora at bay. Science. 2004:303:1624-5.

34. Owusu-Asiedu A, Patience JF, Laarveld B, Van Kessel AG, Simmins PH, Zijlstra RT. Effects of guar gum and cellulose on digesta passage rate, ileal microbial populations, energy and protein digestibility, and performance of grower pigs. J Anim Sci. 2006;84:843-52.

35. Adibmoradi M, Mehri M, Samie A, Shivazad M, Adibmoradi M, Samie A, et al. Effects of $\beta$-mannanase on broiler performance, gut morphology and immune system. Afr J Biotechnol. 2010;9:6221-8.

36. Kim JS, Ingale SL, Lee SH, Kim KH, Kim JS, Lee JH, et al. Effects of energy levels of diet and $\beta$-mannanase supplementation on growth performance, apparent total tract digestibility and blood metabolites in growing pigs. Anim Feed Sci Technol. 2013;186:64-70.

37. LV JN, Chen YQ, Guo XJ, Piao XS, Cao YH, Dong B. Effects of supplementation of $\beta$-mannanase in corn-soybean meal diets on performance and nutrient digestibility in growing pigs. Asian-Australasian. J Anim Sci. 2013:26:579-87.

38. Yoon SY, Yang YX, Shinde PL, Choi JY, Kim JS, Kim YW, et al. Effects of mannanase and distillers dried grain with solubles on growth performance, nutrient digestibility, and carcass characteristics of grower-finisher pigs. Anim Sci. 2010;88:181-91.

39. Carr SN, Allee GL, Rincker PJ, Fry RS, Boler DD. Effects endo-1,4- $\beta-D-$ mannanase enzyme (Hemicell HT 1.5x) on the growth performance of nursery pigs. Prof Anim Sci. 2014;30:393-9.

40. Pettey LA, Carter SD, Senne BW, Shriver JA. Effects of beta-mannanase addition to corn-soybean meal diets on growth performance, carcass traits, and nutrient digestibility of weanling and growing-finishing pigs. J Anim Sci. 2002;80:1012-9.

41. Upadhaya SD, Park JW, Lee JH, Kim IH. Efficacy of $\beta$-mannanase supplementation to corn-soya bean meal-based diets on growth performance, nutrient digestibility, blood urea nitrogen, faecal coliform and lactic acid bacteria and faecal noxious gas emission in growing pigs. Arch Anim Nutr. 2016;70:33-43.

42. Jacela JY, Dritz SS, DeRouchey JM, Tokach MD, Goodband RD, Nelssen J. Effects of supplemental enzymes in diets containing distillers dried grains with solubles on finishing pig growth performance. Prof Anim Sci. 2010:26:412-24

43. Di Paolo NC, Shayakhmetov DM. Interleukin 1a and the inflammatory process. Nat Immunol. 2016;17:906-13.

44. Campos PHRF, Merlot E, Damon M, Noblet J, Le Floc'h N. High ambient temperature alleviates the inflammatory response and growth depression in pigs challenged with Escherichia coli lipopolysaccharide. Vet J. 2014:200:404-9.

45. Buchanan JB, Johnson RW. Regulation of food intake by inflammatory cytokines in the brain. Neuroendocrinology. 2007:86:183-90.

46. Campos PHRF, Labussière E, Dubois S, Renaudeau D, Noblet J. Effects of ambient temperature on energy and nitrogen utilization in lipopolysaccharide-challenged growing pigs. J Anim Sci. 2014;92:4909-20.

47. Rakhshandeh A, Htoo JK, de Lange CFM. Immune system stimulation of growing pigs does not alter apparent ileal amino acid digestibility but 
reduces the ratio between whole body nitrogen and sulfur retention. Livest Sci. 2010;134:21-3.

48. Kluger MJ. The evolution and adaptive value of fever. Am Sci. 1978;66:38-43.

49. Owusu-Apenten R. Inflammation and innate immune response. Bioact Pept Appl Improv Nutr heal. Boca Raton: Taylor and Francis Group; 2010. p. $181-238$

50. Le Floc'h N, Melchior D, Obled C. Modifications of protein and amino acid metabolism during inflammation and immune system activation. Livest Prod Sci. 2004;87:37-45.

51. Reeds PJ, Fjeld CR, Jahoor F. Do the differences between the amino acid compositions of acute-phase and muscle proteins have a bearing on nitrogen loss in traumatic stress? J Nutr. 1994;124:906-10.

52. Kluess J, Kahlert S, Panther P, Diesing A-K, Nossol C, Rothkötter H-J, et al. Systemic E. Coli lipopolysaccharide but not deoxynivalenol results in transient leukopenia and diminished metabolic activity of peripheral blood mononuclear cells ex vivo. Mycotoxin Res. 2015;31:41-50.

53. Williams PN, Collier CT, Carroll JA, Welsh TH, Laurenz JC. Temporal pattern and effect of sex on lipopolysaccharide-induced stress hormone and cytokine response in pigs. Domest Anim Endocrinol. 2009;37:139-47.

54. Rakhshandeh A, Dekkers J, Kerr B, Weber T, English J, Gabler N. Effect of immune system stimulation and divergent selection for residual feed intake on digestive capacity of the small intestine in growing pigs. J Anim Sci. 2012;90:233-5.

55. Koopmans SJ, van der Staay FJ, le Floc'h N, Dekker R, van Diepen JTM, Jansman AJM. Effects of surplus dietary L-tryptophan on stress, immunology, behavior, and nitrogen retention in endotoxemic pigs. J Anim Sci. 2012;90:241-51.

56. Wang M, Chen Y, Zhang Y, Zhang L, Lu X, Chen Z. Mannan-binding lectin directly interacts with toll-like receptor 4 and suppresses lipopolysaccharideinduced inflammatory cytokine secretion from THP-1 cells. Cell Mol Immunol. 2011;8:265-75.

57. Wang M, Zhang Y, Chen Y, Zhang L, Lu X, Chen Z. Mannan-binding lectin regulates dendritic cell maturation and cytokine production induced by lipopolysaccharide. BMC Immunol. 2011;12:1-10.

58. Marinkovic S, Jahreis GP, Wong GG, Baumann H. IL-6 modulates the synthesis of a specific set of acute phase plasma proteins in vivo. J Immunol. 1989;142:808-12.

59. Le Floc'h N, Lebellego L, Matte JJ, Melchior D, Sève B. The effect of sanitary status degradation and dietary tryptophan content on growth rate and tryptophan metabolism in weaning pigs. J Anim Sci. 2009;87:1686-94.

60. Reeds P, Jahoor F. The amino acid requirements of disease. Clin Nutr. 2001; 20:15-22.

61. Weber TE, van Sambeek DM, Gabler NK, Moreland S, Johal S, Edmonds MS Effects of dietary humic and butyric acid on growth performance and response to lipopolysaccharide in young pigs. J Anim Sci. 2014;92:4172-9.

62. Adewole DI, Kim IH, Nyachoti CM. Gut health of pigs: challenge models and response criteria with a critical analysis of the effectiveness of selected feed additives - a review. Asian-Australasian. J Anim Sci. 2016;29:909-24.

63. Demas GE, Chefer V, Talan MI, Nelson RJ. Metabolic costs of mounting an antigen-stimulated immune response in adult and aged C57BL/6J mice. Am J Physiol Integr comp. Physiol. 1997;273:R1631-7.

64. Jin MB, Shimahara Y, Yamaguchi T, Ichimiya M, Kinoshita K, Oka T, et al. The effect of a bolus injection of TNF-alpha and IL-1 beta on hepatic energy metabolism in rats. J Surg Res. 1995;58:509-15.

65. Tsigos C, Papanicolaou D, Defensor R, Mitsiadis C, Kyrou I, Chrousos G. Dose effects of recombinant human interleukin-6 on pituitary hormone secretion and energy expenditure. Neuroendocrinology. 1997;66:54-62.

66. Moon HK, Han IK, Gentry JL, Parmentier HK, Schrama JW. Effects of chronic inflammation on energy metabolism and growth performance in weanling pigs. Asian-Australasian. J Anim Sci. 1999;12:174-9.

67. Williams NH, Stahly TS, Zimmerman DR. Effect of chronic immune system activation on the rate, efficiency, and composition of growth and lysine needs of pigs fed from 6 to $27 \mathrm{~kg}$. J Anim Sci. 1997;75:2463-71.

68. Labussière E, Dubois S, Gilbert $\mathrm{H}$, Thibault JN, Le Floc'h N, Noblet J, et al. Effect of inflammation stimulation on energy and nutrient utilization in piglets selected for low and high residual feed intake. Animal. 2015;9(10): 1653-61.

69. Barnes DM, Song Z, Klasing KC, Bottje W. Protein metabolism during an acute phase response in chickens. Amino Acids. 2002;22:15-26.

70. Shastak Y, Ader P, Feuerstein D, Ruehle R, Matuschek M. B-Mannan and mannanase in poultry nutrition. Worlds Poult Sci J. 2015;71:161-74.

\section{Ready to submit your research? Choose BMC and benefit from:}

- fast, convenient online submission

- thorough peer review by experienced researchers in your field

- rapid publication on acceptance

- support for research data, including large and complex data types

- gold Open Access which fosters wider collaboration and increased citations

- maximum visibility for your research: over $100 \mathrm{M}$ website views per year

At BMC, research is always in progress.

Learn more biomedcentral.com/submissions 